\title{
AUTISM INSURANCE REFORM: A COMPARISON OF STATE INITIATIVES
}

\author{
Melissa Stuart* \\ People are always looking for the single magic bullet \\ that will totally change everything. There is no magic \\ bullet.
}

- Temple Grandin

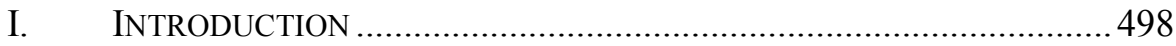

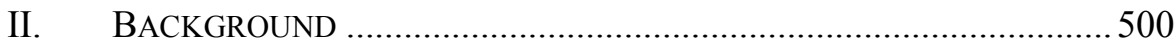

A. Autism Spectrum Disorders ................................................ 500

1. Diagnosis, Symptoms, and Prevalence ............................ 500

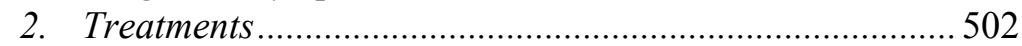

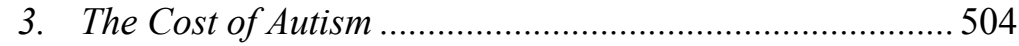

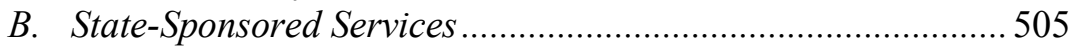

1. Early Intervention Services and the School System........... 505

2. Medicaid Waivers and Other State-Sponsored

Treatment Programs........................................................ 506

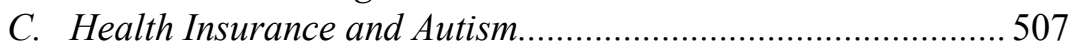

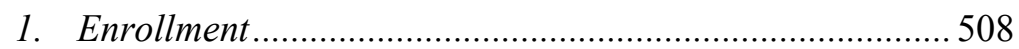

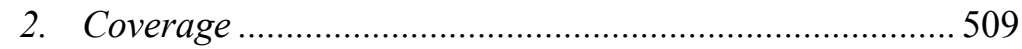

a. ASDs as non-medical conditions ............................... 509

b. ASD treatments ..................................................... 510

(I) Treatment is experimental............................... 510

(II) Treatment is not medically necessary ................511

(III) Treatment is habilitative, custodial, or maintenance ....................................................... 511

(IV) Treatment is considered "educational "............. 512

(V) No qualified in-network providers ..................... 512

3. Consumer Protection Tools................................................. 513

D. Autism Insurance Reform......................................................... 514

1. Current State Autism Insurance Mandates - Common

* J.D. Candidate, 2011, Indiana University School of Law - Indianapolis; B.S., 2003, Virginia Tech; M.S., 2008, Indiana University Purdue University Indianapolis. 


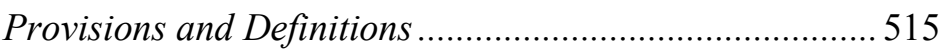

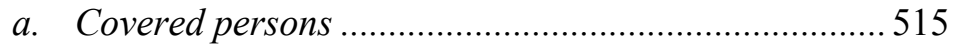

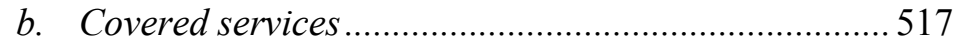

c. Covered providers................................................... 518

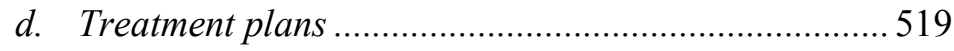

e. Maximum benefit amounts .......................................... 521

f. Prohibiting limits on the number of visits.................. 522

g. Prohibiting termination or refusal to renew a policy. 523

$h$. Types of insurance plans affected .............................. 523

2. Autism Treatment Acceleration Act of 2009 ("ATAA") .... 526

E. Controversies and ASD Insurance Reform .............................. 527

1. Who Should Pay for ASD Services? .................................. 527

2. Financial Impact of ASD Insurance Reform ..................... 529

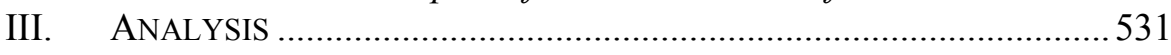

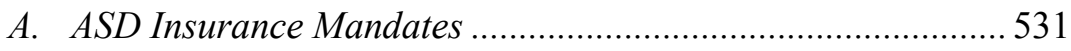

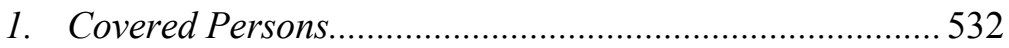

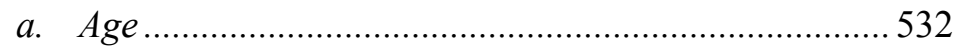

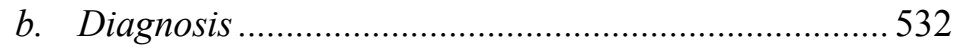

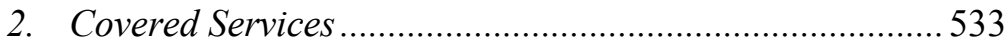

3. Covered Providers................................................................ 534

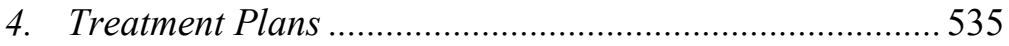

5. Maximum Benefit Amounts.............................................. 536

6. Types of Policies Covered ................................................... 536

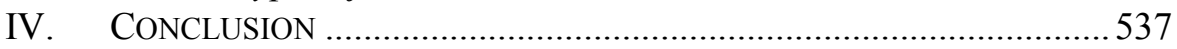

\section{INTRODUCTION}

Imagine the frustration of having a child with a disability, knowing there is a potentially life-changing treatment available but being unable to provide it-because it costs over $\$ 70,000$ a year and is not covered by insurance. To what lengths would you go to provide this treatment for your child, even if it does not turn out to be the magic bullet you were hoping for? Would you take out a second mortgage on your house? Would you exhaust your savings or cash in your retirement accounts? For many parents of children with Autism Spectrum disorders ("ASDs"), this is their reality.

ASDs describe a range of complex neurological disorders characterized by marked impairments in communication and social relatedness and the presence of restricted repetitive or stereotypic patterns of behavior, interests or activities. ${ }^{1}$ ASDs include autistic disorder, Asperger's syndrome,

1. Am. Psychiatric Ass'N, Pervasive Developmental Disorders, in Diagnostic AND Statistical Manual of Mental Disorders 69 (4th ed., text rev. 2000). 
and Pervasive Developmental Disorder, Not Otherwise Specified ("PDDNOS"). Each person with ASD displays an individualized pattern of behaviors or impairments, making a large number of symptom presentations possible. This extreme variability in symptoms and severity makes treatment difficult and costly.

The Autism Society of America ("ASA") estimates that ASDs cost the United States $\$ 60$ billion annually. ${ }^{2}$ However, the cost of lifelong care for each person with autism, according to ASA, can be reduced by two-thirds with early diagnosis and intervention. ${ }^{3}$ Due to dwindling state budgets and the rising incidence of ASDs, many states are not able to adequately address the ASD populations' needs under current state-sponsored programs like Medicaid waivers, early intervention, and special education programs. ${ }^{4}$ Further, many individuals with ASD have difficulty obtaining adequate health insurance, meaning that interventions offered through private providers place an enormous financial burden on families. ${ }^{5}$

Advocates believe the most secure means of accessing treatment for individuals with ASD is through legislatively mandated health insurance coverage. $^{6}$ As of January 2011, twenty-three states have enacted autism insurance mandates. ${ }^{7}$ All but three states have introduced or are proposing

2. This figure includes both direct (i.e., health care, costs to care for individuals with autism) and indirect costs (parent/caregiver missed work, etc.) associated with ASDs, it does not include funds spent on research. Facts and Statistics, AutiSm Soc'Y OF AM., http://www.autism-society.org/site/ PageServer?pagename=about_whatis_factsstats (last visited Jan. 9, 2011).

3. Press Release, Autism Soc'y of Am., ASA Publishes Model Legislation for Autism Insurance Coverage (Feb. 16, 2009), available at http://www.autismsociety.org/site/DocServer/02-16-2009_ASA_Publishes_Model_Legislation_for_Autism_ In.pdf?docID=12061.

4. Autism Speaks, Arguments in Support of Private Insurance Coverage of AutisM-RElATED SERVICES 7 (2009), http://www.autismvotes.org/atf/cf/\%7B2A179B7396E2-44C3-8816-1B1C0BE5334B\%7D/Arguments\%20for\%20private\%20insurance

$\% 20$ coverage.pdf [hereinafter AUTISM SPEAKS, ARGUMENTS].

5. Id. at 4 .

6. See id.

7. Arizona (ARiz. Rev. Stat. $§ 20-826.04$ (LexisNexis 2010)); Colorado (Colo. Rev. Stat. § 10-16-104(1.4) (2010)); Connecticut (ConN. Gen. STAT. § 38a-514b (2010)), Florida (Fla. Stat. § 627.6686 (2010)), Illinois (215 Ill. Comp. Stat. Ann. 5/356z.14 (LexisNexis 2011)); Indiana (IND. CoDE $§ ~ 27-8-14.2$ (2009)); Iowa (IowA CodE ANN. § 514C.26 (West 2010)); Kansas (Kan. Stat. Ann. § 75-6524 (2010)); Kentucky (Ky. Rev. Stat. Ann. § 304.17A-142 (West 2010)); Louisiana (LA. Rev. Stat. AnN. § 22:1050 (2009)); Maine (ME. Rev. Stat. Ann. 24-A, § 2766 (2010)); Massachusetts (Mass. Gen. Laws AnN. 32A, § 25 (West 2010)); Missouri (Mo. AnN. Stat. § 376.1224 (West 2010)); Montana (MonT. Code AnN. § 33-22-515 (2009)); Nevada (Nev. Rev. Stat. AnN. § 689B.0335 (LexisNexis 2010)); New Hampshire (N.H. Rev. Stat. AnN. § 417-E:2 (LexisNexis 2010)); New Jersey (N.J. Stat. AnN. § 17B:27-46.1ii (West 2009)); New Mexico (N.M. Stat. AnN. § 59A-23-11 (LexisNexis 2009)); Pennsylvania (40 PA. StAT. AnN. § 764h (West 2009)); South Carolina (S.C. Code AnN. § 38-71-280 (2008)); Texas (Tex. Ins. Code AnN. § 1355.015 (West 2009)); Vermont (VT. Stat. AnN. 8, § $4088 \mathrm{i}$ (2010)); and Wisconsin (Wis. Stat. § 632.895(12m) (2009)). 
autism insurance reform laws. ${ }^{8}$ Furthermore, there is a proposed federal insurance mandate included in the Autism Treatment Acceleration Act of 2009 ("ATAA"), currently referred to the Senate Health, Education, and Labor Committee, that would require states to mandate coverage for medically necessary therapy for individuals with ASD. ${ }^{9}$

The goal of this Note is to provide a summary of issues leading to the enactment of autism insurance reform, compare current state initiatives, and identify potential concerns in current legislative language. The first section provides a background on ASDs, including treatments, costs, and the current system for providing services. The next section provides a background on the health insurance industry's treatment of ASDs that led to the development of autism insurance reform. It includes information on riskshielding techniques used by the industry and available consumer protection tools. The third section presents current state and federal autism insurance initiatives and specifically examines common provisions and controversies surrounding autism insurance mandates. The final section identifies problems with the current state and federal autism insurance reform initiatives and offers suggestions for addressing those issues.

\section{BACKGROUND}

\section{A. Autism Spectrum Disorders}

\section{Diagnosis, Symptoms, and Prevalence}

Autism is a complex neurological disorder characterized by marked impairments in communication and social relatedness and the presence of restricted repetitive or stereotypic patterns of behavior, interests or activities. ${ }^{10}$ Autism is on the lower end of a spectrum of Pervasive Developmental Disorders ("PDDs") with Asperger's syndrome at the high end and Pervasive Developmental Disorder, Not Otherwise Specified ("PDD-NOS") typically somewhere in the middle. ${ }^{11}$ These three separate diagnoses are often referred to as Autism Spectrum Disorders (“ASDs"). ${ }^{12}$ ASDs are di-

8. As of January 2011, Oklahoma, Utah, and Wyoming are currently not pursuing autism insurance reform. See 2011 State Initiative Agenda: Current Status of State Autism Insurance Reform Bills, AUTISM SPEAKS (Jan. 7, 2011), http://www.autismvotes.org/atf/cf/ \%7B2A179B73-96E2-44C3-8816-1B1C0BE5334B\%7D/State\%20Map\%20-\%201.7.11.pdf. (2009)

9. Autism Treatment Acceleration Act of 2009 (ATAA), S. 819, 111th Cong. $\S 12$

10. AM. PsYChiATRIC Ass'N, supra note 1, at 70-71.

11. The spectrum refers to severity and characteristics of symptoms. 299.00 Autistic Disorder, Am. PSYChIATRIC Ass'N. (2010), http://www.dsm5.org/ProposedRevisions/Pages/ proposedrevision. aspx?rid=94\#.

12. Id. Autism Spectrum Disorders is a colloquial term used to describe the three most common PDDs, however, the term will likely be adopted as the medical term in the next 
agnosed by physicians, psychiatrists, or clinical psychologists through observational methods and interviews with the child's caregivers; ${ }^{13}$ there are currently no approved medical tests to accurately confirm a diagnosis. ${ }^{14}$

Despite their conceptualization as points on the same spectrum, there are important differences among the three ASD diagnoses. Asperger's syndrome differs from autism because with Asperger's syndrome there is no delay in language or cognitive development. ${ }^{15}$ Because people with Asperger's syndrome have marked impairments with social interactions, many children are not diagnosed until they reach grade school age when social problems become more apparent. ${ }^{16}$ Children with autism, on the other hand, must have symptoms present prior to age three but can be identified as early as two years old. ${ }^{17}$ PDD-NOS requires that there be impairment in reciprocal social interaction with an impairment in communication skills or the presence of stereotyped behaviors, interests, or activities, but some criteria of typical autism may be lacking, such as a late onset of symptoms or failure to meet all the three symptom clusters. ${ }^{18}$

Each person with ASD presents with an individualized pattern of behaviors or impairments making a large number of symptom presentations possible. The severity of these disorders varies along a continuum, with some individuals having more profound problems in one key diagnostic area than others. ASDs are associated with the full range of cognitive abilities, from profoundly mentally impaired to exceptionally bright. ${ }^{19}$

In addition to the diagnostic symptoms, individuals with ASD often have underlying co-morbid health issues. ${ }^{20}$ Seizures affect as many as twenty-five percent of individuals with ASD. ${ }^{21}$ Additionally, many individuals experience anxiety, depression, sensory disturbance, hyperactivity, attention-deficit, gastro-intestinal problems, ear infections, allergies, and

edition of the DSM. The other PDDs, Rett's disorder and Childhood Disintegrative Disorder ("CDD"), are less common and not currently considered part of the autism spectrum. However, DSM-5 proposes to phase out Rett's disorder altogether as a PDD and include CDD as an ASD.

13. See, e.g., Catherine Lord et al., Autism Diagnostic Interview-Revised: A Revised Version of a Diagnostic Interview for Caregivers of Individuals with Possible Pervasive Developmental Disorders, 24(5) J. AUTISM \& DEV. DisORDERs 659, 660 (1994), available at http://infantlab.fiu.edu/articles/ Lord,Rutter,LeCouteur_1994\%20JADD.pdf.

14. Despite the reliance on observation and interview, the use of Magnetic Resonance Imaging ("MRI") to diagnose autism is possible in the near future. See A Major Step in Diagnosing Autism Through MRI, AUTISM SoC'Y OF AM. (Oct. 21, 2010), http://www.autismsociety.org/site/News2 ?page=NewsArticle\&id=16562\&news_iv_ctrl=1882.

15. AM. PSYCHIATRIC ASS'N, supra note 1, at 80.

16. Id. at 81 .

17. Id. at 71 .

18. $I d$. at 84 .

19. $I d$. at $69,71,81$.

20. Id. at 72 (including chromosomal abnormalities, congenital infections, and structural abnormalities of the central nervous system).

21. Id. 
sleep disorders. ${ }^{22}$ Due to the wide range of additional medical problems associated with ASD, access to medical care is important.

ASDs affect every race, ethnicity, and socioeconomic status. However, ASDs increasingly affect males compared to females. ${ }^{23}$ In 2000, it was estimated that between two to and twenty children out of every 10,000 had autism. ${ }^{24}$ In 2006, the Centers for Disease Control estimated that one out of every one hundred children has an ASD. ${ }^{25}$ The prevalence of ASDs is increasing dramatically in every state, ${ }^{26}$ each lacking an adequate system to support their needs. ${ }^{27}$

\section{Treatments}

There is no cure for autism. ${ }^{28}$ However, with intervention, many individuals with ASD can make significant improvements in decreasing symptoms and living independently. ${ }^{29}$ There are several recommended interventions for ASDs including behavioral, speech, occupational, and physical therapy, as well as medications to address symptoms associated with ASDs. ${ }^{30}$

A commonly prescribed treatment protocol, and the most controversial in the fight for insurance coverage, is Applied Behavior Analysis ("ABA"). ABA is a toolbox of behavioral modification principles based on theories of learning and operant conditioning. ${ }^{31}$ The goal is to reinforce appropriate behaviors like communication, socialization, and self-help skills, and decrease problem behaviors like stereotyped or repetitive movements, self-

22. $I d$.

23. Id. at 73 (noting rates of autism are four to five times higher in males than in females).

24. $I d$.

25. Autism and Developmental Disabilities Monitoring Network (ADDMN), Prevalence of Autism Spectrum Disorders, CENTERS FOR DISEASE CONTROL (2006), http://www.cdc.gov/ mmwr/preview/mmwrhtml/ss5810a1.htm. A discussion relating to the dramatic increase in the number of children with ASDs in the past decade is outside the scope of this Note. However, many factors likely contribute to the increase including increased physician awareness, an expansion of the diagnostic criteria in 1994 to include individuals with Asperger's syndrome, and the development of more readily available screening measures.

26. See id.

27. Autism SpeAKS, Arguments, supra note 4 , at 4.

28. Nat'l Inst. of Child Health and Human Dev. ("NICHD”), NIH Pub No. 055592, AutisM OVERVIEw 7 (2005), available at http://www.nichd.nih.gov/publications/pubs/ upload/autism_overview_2005.pdf [hereinafter, NIH Pub No. 05-5592].

29. S. $12 \overline{7}$, Gen. Assemb., Reg. Sess. (Vt. 2010) § 1(3) (finding that, "Research strongly indicates that early detection, diagnosis, and treatment of children with autism spectrum disorders result in significant improvements in functioning ...").

30. NIH PuB No. 05-5592, supra note 28, at 10.

31. Id. at 8 . 
injury, and aggression. ${ }^{32}$ Researchers have successfully posited several models of ABA interventions. ${ }^{33}$ While the core behavior modification principles remain the same, the intensity, frequency, duration, setting, and therapist characteristics may change based on the intervention model used. Researchers are still working to find the right combination of factors that produce the best results. However, all agree that early intensive intervention is key to compounding the positive effects of any ABA therapy model. $^{34}$ With early intervention, children with autism have shown improvements in IQ, language, academic performance, adaptive behaviors, and social skills. ${ }^{35}$

One intervention model with demonstrated success involves intensive treatment requiring thirty to forty hours of therapy a week for several years. ${ }^{36}$ Half the children treated with these intensive behavioral intervention models can overcome their autistic characteristics such that they are indistinguishable from their peers. ${ }^{37}$ Recently, researchers at the Center for Autism and Related Disorders found that forty-three percent of children with autism participating in their study who received an ABA-based program consisting of at least twenty-five hours per week of treatment no longer displayed clinical symptoms of autism and demonstrated improvements in functioning. ${ }^{38}$

Because ABA therapy involves a great deal of time, it is quite expensive and most medical insurance policies do not cover it. ${ }^{39}$ Wealthy parents may pay thousands of dollars a year ${ }^{40}$ and less fortunate children likely go

32. Id.

33. See id.

34. See S. 127, Gen. Assemb., Reg. Sess. (Vt. 2010) § 1(3); Autism SpeAKS, ARGUMENTS, supra note 4, at 9.

35. See, e.g., Study Reveals Children Recover from Autism with Intensive Three-Year Behavioral Therapy, Medical News Today (Nov. 13, 2010, 1:00 PM PST), http://www.medicalnewstoday.com/articles/207798.php; S. 127, Gen. Assemb., Reg. Sess. (Vt. 2010) $\S \S 1(3)(\mathrm{A}),(\mathrm{B}),(\mathrm{C})$.

36. Autism Speaks, Arguments, supra note 4, at 9.

37. Id.

38. Study Reveals Children Recover from Autism with Intensive Three-Year Behavioral Therapy, supra note 35.

39. See Justine Redman, Mom Wins First for Autism Insurance, CNN (Apr. 1, 2008), http://www.cnn.com/2008/HEALTH/conditions/04/01/autism.insurance/index.html?iref=alls earch; Abt. Associates, Inc., Autism Spectrum Disorders Mandated Benefits Review Panel Report: Evidence Submitted Concerning Pennsylvania HB 1150, at 7 (June 18, 2008), available at http://www.autismvotes.org/atf/cf/\%7B2A179B73-96E2-44C3-88161B1C0BE5334B\%7D/HC4AutismPanelReport061808.pdf [hereinafter PENNSYLVANIA HB $1150]$.

40. See Redman, supra note 39 (estimating $\$ 70,000$ - $\$ 80,000$ per year); Sarah Mueller, Health Care Law May Help Families with Autism Costs, Dallas Morning News (May 11, 2010, 9:02 AM CDT), http://www.dallasnews.com/sharedcontent/dws/news/city/ collin/plano/stories/051110 dnmetautism.41d0d68.html (reporting that parent pays $\$ 5,000$ per month for ASD services); PENNSYLVANIA HB 1150, supra note 39, at 13 (quoting a parent who spent approximately $\$ 600,000$ in ASD services in the past twelve years). 
without therapy. ${ }^{41}$ Without early intensive ABA therapy, children with ASD are likely to place a large financial strain on the state through placements in costly special education programs or institutionalization in state hospitals. $^{42}$

\section{The Cost of Autism}

The societal cost of autism is estimated at $\$ 35$ billion to care for all individuals with autism over their lifetime. ${ }^{43}$ This cost is driven by both direct and indirect costs. ${ }^{44}$ Direct costs are incurred, like any child, through expenses associated with routine medical and dental care. ${ }^{45}$ However, children with ASD use health care services more frequently than typically developing children and are responsible for higher health care costs. ${ }^{46}$

Indirect costs associated with ASD include lost productivity by parents who may reduce the hours they work outside the home or forego outside employment entirely to care for their child. ${ }^{47}$ Indirect costs also include productivity lost for adults with ASD who are unable to work. ${ }^{48}$ These costs have enormous ramifications for society's tax base as children with ASD transition into adulthood. If a child with an ASD is not properly treated, the societal cost for that one child over his or her lifetime could be as high as $\$ 3.2$ million. ${ }^{49}$ The costs associated with caring for an individual with ASD have led many states to sponsor treatment programs through public schools and Medicaid waiver programs.

41. See S. 127, Gen. Assemb., Reg. Sess. (Vt. 2010) § 1(4) (reporting on a survey which found that approximately fourteen percent of children with an ASD had foregone care, thirty-eight percent of families of children with an ASD had financial problems caused by their child's health care, and thirty-five percent of families noted needing additional income to cover medical expenses).

42. See, e.g., S. 127, Gen. Assemb., Reg. Sess. (Vt. 2010) § 1(7), (8); see also Pennsylvania HB 1150, supra note 39, at 11, 25.

43. Michael L. Ganz, The Lifetime Distribution of the Incremental Societal Costs of Autism, 161 Archives of Pediatrics \& Adolescent Med. 343, 343 (2007).

44. Id. at 344 (explaining that direct costs include the values of goods and services used, whereas indirect costs include value of lost productivity both from the adults with autism unable to work and from parents who reduce work hours in order to care for their child).

45. Id.

46. See Id. at 348; Pennsylvania HB 1150, supra note 39, at 20.

47. See S. 127, Gen. Assemb., Reg. Sess. (Vt. 2010) § 1(4) (noting a national survey which found that fifty-seven percent of families of children with an ASD had a family member reduce or stop employment because of the child's condition, and twenty-seven percent of families reported spending ten or more hours per week providing or coordinating care for their child).

48. Ganz, supra note 43 , at 344.

49. Id. at 343; S. 127, Gen. Assemb., Reg. Sess. (Vt. 2010) § 1(1). 


\section{B. State-Sponsored Services}

Traditionally, states provide services to individuals with ASD through various agencies and state-funded programs. These services are expensive. For example, in 2009, Indiana's Bureau of Developmental Disabilities Services ("BDDS"), the state agency responsible for administering services, spent approximately $\$ 536$ million on services for individuals with ASDs and other developmental disabilities. ${ }^{50}$ Consequently, the increased prevalence of ASD coupled with dwindling state budgets has created a system that cannot possibly support the burgeoning need.

\section{Early Intervention Services and the School System}

Under the 2004 reauthorization of the Individuals with Disabilities Education Act ("IDEA"), early intervention and special education programs must provide services and treatments to children with ASDs. ${ }^{51}$ Early intervention programs typically include children from birth to three years old who have a developmental delay. ${ }^{52}$ In 2009, Indiana served approximately 10,000 children at an estimated cost of $\$ 34$ million in its early intervention program. ${ }^{53}$ Unfortunately, because services stop at age three, many children with autism who are unable to be diagnosed until approximately eighteen months old cannot take advantage of these types of programs for very long, if at all.

With respect to the school setting, IDEA only requires services when the child's exceptionalities affect his or her ability to receive an education. ${ }^{54}$ Therefore, higher functioning children or children with Asperger's syndrome, for example, would likely be excluded from receiving treatment through the school. Additionally, problems associated with treating individuals with ASD are too numerous to be dealt with through the public school system alone. ${ }^{55}$ According to a 2005 Government Accounting Of-

50. Peter A. Bisbecos, Director, January Monthly Financial Review, Div. DisabiLity \& Rehabilitative Serv., Indiana Family \& Social Serv. Admin. 2 (Feb. 26, 2009), http://www.in.gov/fssa/files/2.09_DDRS_MFR.pdf. See also S. 127, Gen. Assemb., Reg. Sess. (Vt. 2010) § 1(2) (reporting that Vermont spent an estimated $\$ 57$ million on services for individuals with ASDs in 2007).

51. 34 C.F.R. $§ 300.101$ (2006) (Part B, Education Services); 34 C.F.R. $§ 300.226$ (2006) (Part C, Early Intervention covering children birth to three years old); see also NIH PuB No. 05-5592, supra note 28, at 9; see, e.g., Bisbecos, supra note 50, at 36 (stating that First Steps is Indiana's early intervention program).

52. 34 C.F.R. $\S 300.226$; see, e.g., Bisbecos, supra note 50, at 36.

53. Bisbecos, supra note 50 at 37,39 . It is impossible to tell how much of that total is attributed to individuals with ASDs as data are not available by diagnosis for this age group.

54. 34 C.F.R. $\S 300.101$; see also NIH PUB No. 05-5592, supra note 28, at 9.

55. See Victoria C. Bunce \& J.P. Wieske, The Growing Trend Toward Mandating Autism Coverage, 152 ISSUES \& ANSWERS at 1 (Mar. 2009), available at http://www.cahi.org/cahi_contents/resources/pdf/n152AutismTrend.pdf (noting only three 
fice report, the average expenditure per pupil for educating a child with autism was more than $\$ 18,000$ in the 1999-2000 school year, almost three times the average per pupil expenditure of educating a child who does not receive any special education services. ${ }^{56}$ Similarly, Vermont reported in 2009 spending an average of $\$ 42,500$ per child annually for students with ASD, totaling approximately $\$ 765,000$ per child over eighteen years of education. ${ }^{57}$ However, early behavioral intervention could result in a savings of "near or above $\$ 200,000$ per child over the course of the child's educational career."

\section{Medicaid Waivers and Other State-Sponsored Treatment Programs}

Medicaid waivers are Home and Community-Based Services ("HCBS") waivers provided by many states to persons with developmental disabilities or long-term illnesses. ${ }^{59}$ Services provided under a Medicaid waiver help a person live at home or within their community instead of in an institution. ${ }^{60}$ Several states, including Indiana, have autism or developmental disability-specific Medicaid waivers. ${ }^{61}$ In 2009, Indiana's Medicaid spending for waiver services totaled approximately $\$ 288$ million. ${ }^{62}$

However, only a certain number of people can be served by a waiver leading to a backlog of individuals waiting for a spot to open up. ${ }^{63}$ Due to

percent of children with autism have their needs met under IDEA); B.D. v. DeBuono, 130 F. Supp. 2d 401, 401 (S.D.N.Y. 2001) (noting concerns of parents of children with autism who are claiming public schools unlawfully implemented policies to prevent, discourage, or limit the use of ABA). See also Stacy K. Dymond, Christie L. Gilson, \& Steve P. Myran, Services for Children with Autism Spectrum Disorders, 18 J. Disability PoL'y STUD. 133, 134, 143 (2007), available at $\mathrm{http}: / / \mathrm{dps}$.sagepub.com/content/18/3/133.full.pdf $+\mathrm{html}$.

56. U.S. Gov't Accountability Office, GAO-05-220, Special Education: CHILDREN WITH AUTISM, at 2 (2005), available at http://www.gao.gov/new.items /d05220.pdf.

57. S. 127, Gen. Assemb., Reg. Sess. (Vt. 2010) § 1(8).

58. S. 127, Gen. Assemb., Reg. Sess. (Vt. 2010) § 1(6) (citing two studies in its findings in favor of coverage for autism services). See also Gregory S. Chasson, Gerald E. Harris, \& Wendy J. Neely, Cost Comparison of Early Intensive Behavioral Intervention and Special Education for Children with Autism, 16 J. CHILD FAM. STUD. 401, 401 (2007) (finding that the state of Texas would save a total of $\$ 2.09$ billion with early intensive behavioral intervention).

59. Ind. Governor's Council for People with Disabilities, Indiana Medicaid Home and Community-Based Services Waiver Programs: A Guide for Consumers 6 (4th ed. 2007), available at http://www.in.gov/fssa/files/ConsumerWaiverGuideW200703 .pdf.

60. Id. They are called waivers because the programs typically waive or reduce the income requirements of traditional Medicaid programs.

61. See, e.g., Id. at 7.

62. Bisbecos, supra note 50, at 5.

63. Marci Wheeler, Indiana's Home and Community Based Waivers, 12(2) THE REPORTER 3, 5 (2007), available at http://www.iidc.indiana.edu/index.php?pageId=555. See also Bisbecos, supra note 50, at 12 (noting that in 2009, Indiana had 18,855 individuals on waiting lists for all Medicaid waiver programs). 
tremendous waiting lists, it is unlikely an individual will get a Medicaid waiver during the period immediately following diagnosis when intervention would be most effective.

Aside from the limited number of individuals the waivers are able to assist ${ }^{64}$ the services provided to those who qualify are often deficient in quality of personnel and standards of care. Medicaid suffers from low reimbursement rates, which makes it difficult for many organizations to retain qualified service providers. ${ }^{65}$ Moreover, services accessed through the Medicaid system are often inadequate to meet the specific needs of a child with autism. ${ }^{66}$ For example, a Pennsylvania panel reviewing the need for autism insurance reform noted that, "Pennsylvania's Medicaid waiver program is fragmented, does not cover all of those in need, and has inadequate payment schedules for at least some providers and specific services." ${ }^{, 67}$ Therefore, while Medicaid waiver programs offer much needed assistance, they often help too few and are inundated with problems. ${ }^{68}$

To summarize, ASDs are complicated disorders with a dramatically increasing prevalence rate and expensive treatments that cannot be supported by the current state-funded systems. Faced with such a dire situation, many states explore alternative methods of providing services to its citizenry - in this case, health insurance.

\section{Health Insurance and Autism}

Individuals with ASD may seek insurance coverage through a variety of means. Children with ASD are likely to enroll as dependents on their parent's health insurance plan or under state-sponsored health insurance programs. $^{69}$ However, as adults, individuals with ASD would be able to continue coverage under their parent's health insurance plan only if they are

64. See, e.g., Bisbecos, supra note 50, at 7 (noting that a total of 11,109 individuals receiving waiver services with only 7,093 receiving comprehensive waiver services).

65. Autism SpeaKs, ARguments, supra note 4, at 8.

66. See Dymond, Gilson, \& Myran, supra note 55, at 134 ("Frequently, individuals who are responsible for providing services to children with ASD . . . lack specific training in ASD. Although services may be available ... [services] may not result in desired outcomes if the provider is ineffective in delivering them.").

67. Pennsylvania HB 1150, supra note 39 , at 5.

68. See, e.g., Hummel v. Ohio Dep't of Job \& Family Serv., 844 N.E.2d 360, 361 (6th Cir. 2005) (finding that the state Medicaid program denied ABA treatment because it was not the lowest cost alternative); Parents League for Effective Autism Serv. v. Jones-Kelley, 565 F. Supp. 2d 905, 910 (S.D. Ohio 2008) (finding that a denial of ABA therapy following an amendment to the state's Medicaid plan was to avoid having to pay for services); Rosie D. v. Romney, 410 F. Supp. 2d 18, 52 (D. Mass. 2006) (finding that the state failed to meet the Medicaid Act's mandate to provide services with reasonable promptness and also failed to provide supports at adequate levels of duration and intensity).

69. See, e.g., What is SCHIP, SCHIP INFORMATION CTR., http://www.schip-info.org/ (last visited Jan. 9, 2011). 
considered a legal and disabled dependent. ${ }^{70}$ If the individual does not qualify for Medicaid or receive benefits through an employer, the only option available is for individual coverage.

Because individuals with ASD use a disproportionate amount of health care services, insurance companies have historically attempted to minimize the risk associated with providing coverage for this group. ${ }^{71}$ There are two main ways insurers exclude people with ASDs from coverage: (1) through enrollment practices; and (2) through limitations and exclusions in the terms of coverage. ${ }^{72}$

\section{Enrollment}

Typically, when a person applies for individual health insurance coverage, the company goes through an underwriting process to evaluate the risk posed by insuring that individual. ${ }^{73}$ Some people are considered too big a risk to be permitted to enroll, or may enroll only under pre-existing condition exclusions designed to protect the group from expensive health conditions present at the time of enrollment. ${ }^{74}$ Pre-existing condition exclusions allow enrollment while imposing total exclusions for pre-existing conditions or, in some cases, waiting periods for coverage of pre-existing conditions. $^{75}$ For individuals with an ASD, this means that they may have more difficulty obtaining coverage, would only be covered for medical services not associated with their diagnosis, or if subject to a waiting period, would have to wait a specific period of time before receiving coverage. ${ }^{76}$ With the recent health care reform, insurers may be prohibited from exclud-

70. See, e.g., Indiana State Personnel DePt., Form 53388(10-07), Verification of DEPENDENT DisABILITY STATUS (2007), available at http://www.in.gov/icpr/webfile/ formsdiv/53388.pdf. Criteria generally include the disability to have occurred before age 19, affirmation that the dependent is unable to engage in gainful employment because of his or her disability, and annual documentation from a physician.

71. See, e.g., Pervasive Developmental Disorders, Clinical Policy Bulletin 0648 (Aetna), http://www.aetna.com/cpb/medical/data/600_699/0648.html (last visited Dec. 18, 2009); Medical Policy, BEH.00004 (Anthem) http://www.anthem.com/medicalpolicies/ policies/mp_pw_a050279.htm (last visited Dec. 18, 2009) (stating policies limiting what is covered for ASDs).

72. See Symposium, Legal Solutions in Health Reform: Insurance Discrimination on the Basis of Health Status, 37 J.L. MED. \& ETHICs 103, 106 (2009) [hereinafter Symposium].

73. Id. at 105.

74. Id.

75. Id. at 107.

76. Press Release, Illinois Dep't. of Ins., Insurance Coverage for Autism, at 3 (rev. Oct. 2009), available at http://www.insurance.illinois.gov/pressRelease/pr08/ AutismFactSheet.pdf [hereinafter Press Release, Ill. DOI] (noting that Illinois law allows insurance companies to exclude coverage for pre-existing conditions, including autism, for up to two years). See also PenNSylvania HB 1150, supra note 39, at 7 (noting a study that found all of the forty-six insurers surveyed to exclude autism). 
ing children with pre-existing conditions from coverage. ${ }^{77}$

Individuals with autism who are permitted to enroll may be charged higher premiums. ${ }^{78}$ Underwriting permits the adjustment of premiums to reflect the anticipated level of financial risk. ${ }^{79}$ Individuals whose characteristics (i.e., health status and personal characteristics that predict health status and insurance use) pose higher financial risks would pay a higher premium. Sometimes charging a significantly higher premium is enough to render coverage unaffordable, thus, constructively barring someone from enrolling. Fortunately, as discussed below, autism insurance mandates include a provision prohibiting insurance companies from charging a higher premium solely because the individual has an ASD. ${ }^{80}$ However, laws aimed at disabling a company's ability to control financial risk at the point of enrollment can lead to an increased use of risk-shielding tools in the policy's terms of coverage. ${ }^{81}$

\section{Coverage}

Post-enrollment risk-shielding limits the amount, duration, or scope of coverage. There are several ways that insurance companies have avoided covering services for individuals with ASD including: treating ASDs as non-medical conditions; finding treatments to be experimental, educational, not medically necessary, or habilitative in nature; or denying claims because there is no qualified provider.

\section{a. ASDs as non-medical conditions}

As a threshold matter, insurance companies are historically unsure how to deal with autism as a diagnosis. Some classify it as mental illness, which would place it under mental health coverage. ${ }^{82}$ Others classify it as a chronic illness, placing treatments in the long-term care category. ${ }^{83}$ The designation is important in determining whether ASDs are covered at all, as some health plans do not offer coverage for mental health or long-term disability. ${ }^{84}$ Some states, like Indiana, have resolved this issue by specifically defining autism as a neurological disorder that falls under medical insurance coverage. ${ }^{85}$ This means that an insurer in Indiana cannot classify ASDs as

77. See Mueller, supra note 40.

78. Symposium, supra note 72 , at 106.

79. Id. at 105.

80. See infra Part II.D.1.h.

81. See Symposium, supra note 72 , at 106.

82. See, e.g., Wis. StAT. § 632.895(12m)(a)(5) (2009); see also Bunce \& Wieske, supra note 55 , at 1 .

83. Bunce \& Wieske, supra note 55 , at 1.

84. Pervasive Developmental Disorders, supra note 71.

85. IND. CODE $§ 27-8-14.2-3$ (2009) ("Pervasive developmental disorder means a neu- 
mental health disorders or use mental health exclusions to limit coverage. ${ }^{86}$

Even when ASD's designation as a medical condition is not in question, there are other ways insurance companies attempt to exclude coverage. One way is to deny coverage for ASDs based on the person's diagnosis. ${ }^{87}$ For example, in Illinois, an insurance carrier denied coverage for speech therapy because the plan excluded therapies for conditions of developmental delay, learning or educational problems, and non-restorative medical conditions even though speech therapy would be available to treat other conditions. $^{88}$

\section{b. ASD treatments}

Another way insurance companies attempt to avoid paying claims for ASD treatment is by focusing on the treatment or the provider. Insurance companies have an arsenal of tools for denying coverage for services to treat ASD symptoms, many of which are discussed below. ${ }^{89}$

\section{(I) Treatment is experimental}

To promote the use of effective, scientifically valid treatments, insurers may limit coverage to evidence-based treatments. Because of the extreme variability in symptom presentation for individuals with ASDs, efforts to identify treatments that meet the health insurance industry's standards for evidence-based treatments are difficult for researchers to achieve. Insurance companies argue that autism is an individually based disorder, and so there is often no clear standard of care. ${ }^{90}$ Therefore, health insurance carriers that provide coverage for autism may classify certain therapies as "experimental and investigational," thereby excluding those

rological condition.”); CoLO. REv. STAT. § 10-16-104(1.4)(III) (2010) (stating that ASD is a neurobiological disorder); CONN. GEN. STAT. § 38a-514b(b) (2010) (classifying ASD as an “illness"). But see N.H. ReV. StAT. AnN. § 417-E:2 (LexisNexis 2010) (defining ASDs as biologically-based mental illness).

86. Michelle Trivedi, Indiana's Health Insurance Mandate for Autism Spectrum Disorders (ASDs) and Pervasive Developmental Disorders (PDD's), INDIANA INST. ON DisABILITY AND COMMUNITY, http://www.iidc.indiana.edu/index.php? pageId=547 (last visited Jan. 10, 2011).

87. PenNSylvania HB 1150, supra note 39 (noting a study that found all forty-six commercial employment-based health insurance policies surveyed excluded autism as a medical condition).

88. Wheeler v. Aetna Life Ins. Co., No. 01 C 6064, 2003 U.S. Dist. LEXIS 12742, at *40 (N.D. Ill. Jul. 21, 2003). See also, Morgenthal v. American Telephone \& Telegraph Co., Inc., 97 Civ. 6443, 1999 U.S. Dist. LEXIS 4294, at*5 (S.D.N.Y. Apr. 5, 1999) (stating that insurer refused coverage for autism treatments because it was considered a developmental disorder).

89. See McHenry v. PacificSource Health Plans, CV-08-562-ST, 2010 U.S. Dist LEXIS 321, at*323 (D. Ore. Jan. 5, 2010); Redman, supra note 39.

90. Bunce \& Wieske, supra note 55, at 2. 
therapies from coverage. ${ }^{91}$ ABA therapy, in particular, is often considered experimental despite its proven effectiveness. ${ }^{92}$

\section{(II) Treatment is not medically necessary}

Another way insurance companies attempt to avoid coverage for ASD is to determine that the therapies are not medically necessary. ${ }^{93}$ Plans differ in the precise language but generally, medically necessary services are those that the plan's administrator considers appropriate for the treatment and diagnosis of a covered illness. ${ }^{94}$ Insurers may deny coverage for therapies based on a lack of medical necessity even if a treating physician prescribes the service. ${ }^{95}$

\section{(III) Treatment is habilitative, custodial, or maintenance}

Sometimes services available for medical conditions in the short-term are excluded for use as long-term therapy for individuals with ASD. ${ }^{96}$ One justification for excluding ASD treatments otherwise covered for other conditions is that insurers do not believe such therapies have a "reasonable expectation of achieving sustainable, measurable improvement in a reasonable and predictable period of time." 97 When restoration of previous functioning is required, it automatically eliminates the "potential for covering treatments whose medical purpose is to help a patient attain, maintain, or avert the loss of functioning." 98

91. See Bussey v. Corning Life Serv., Inc., No. 97CV8875, 2000 U.S. Dist. LEXIS 658 , at $* 6$ (N.D. Ill. 2000).

92. See Carey v. Conn. Gen. Life Ins. Co., Civ. No. 02-3642(JNE/JSM), 2004 U.S. Dist. LEXIS 3823, at *2 (D. Minn. Mar. 8, 2004); McHenry, 2010 U.S. Dist. LEXIS 321, at *3; see also Pervasive Developmental Disorders, supra note 71; Medical Policy, supra note 71.

93. Minutes from the Tex. Dep't Ins., at 7 (Dec. 5, 2008), available at http://www.tdi.state.tx.us /hmo/documents/120508asdminutes.pdf [hereinafter Minutes]; Press Release, Ill. DOI, supra note 76, at 3.

94. Bails v. Blue Cross/Blue Shield of Ill., 438 F. Supp. 2d 914, 918 (N.D. Ill. 2006); Hummel v. Ohio Dep't of Job and Family Serv., 844 N.E.2d 360, 363 (6th Cir. 2005). Generally medically necessary treatments are identified in a person's policy.

95. Bussey, 2000 U.S. Dist. LEXIS 658, at*3.

96. See, e.g., Pervasive Developmental Disorders, supra note 71 , at (P).

97. Pennsylvania HB 1150, supra note 71, at 7. See also Bails, 438 F. Supp. 2d at 920; In re Micheletti v. State Health Benefits Comm., 913 A.2d 842, 845-46 (N.J. Super. Ct. App. Div. 2007); KAN. STAT. ANN. § 75-6524(a)(7)(B) (allowing an insurer to deny a claim if the covered individual has reached the maximum medical improvement). But see, N.M. STAT. ANN. § 59A-23-11(B)(3) (LexisNexis 2009) (prohibiting treatment from being denied on the basis that the "services are habilitative or rehabilitative in nature").

98. Symposium, supra note 75, at 107. 


\section{(IV) Treatment is considered "educational"}

Another way insurers deny coverage for some ASD treatments is by categorizing the treatments as educational. ${ }^{99}$ States are required to provide certain services, including ABA and other therapies, if it will help the individual receive an education. ${ }^{100}$ Therefore, insurance companies have historically not covered services that are available through the school. Speech and ABA therapy are typical targets for exclusion as educational interventions. ${ }^{101}$ For example, Aetna's description of ABA therapy stresses the role of education and identifies it specifically as an excluded educational intervention. ${ }^{102}$

\section{(V) No qualified in-network providers}

Another way insurance companies are able to deny coverage for ABA in particular is to deny the treatment because it is not administered by a qualified or credentialed provider. ${ }^{103}$ The bulk of intensive ABA therapy may be administered by an unlicensed, uncertified provider (typically a college student, recent college graduate, or parent), with a certified provider overseeing the treatment. ${ }^{104}$ While there is national certification for both the supervisor and the direct care provider, ${ }^{105}$ several states do not recognize those certifications for obtaining a state license. ${ }^{106}$

99. See Pervasive Developmental Disorders, supra note 71; Medical Policy, supra note 71 .

100. See supra section II B 1.

101. See Pervasive Developmental Disorders, supra note 71; Medical Policy, supra note 71. See also Bunce \& Wieske, supra note 55, at 2.

102. Pervasive Developmental Disorders, supra note 71.

103. Carey v. Conn. Gen. Life Ins. Co., Civ. No. 02-3642 (JNE/JSM), 2004 U.S. Dist. LEXIS 3823, at *2 (D. Minn. Mar. 8, 2004) (denying ABA therapy because there was no "license, credentialing or medical supervision of the program."); LOUISIANA DEP'T OF INS., ACT 648 AUTISM INSURANCE TIP SHEET, at 2 (Jan. 20, 2009), available at www.laddc.org/main/wp-content/uploads/2009/01/act-648-parent-tips-12009.pdf [hereinafter LA ACT 648 TIP SHEET] (noting, "Without being credentialed by the insurance plan the provider of ABA treatments will not be able to seek reimbursement.").

104. Trivedi, supra note 86.

105. See Becoming Certified: Standards and Applications for Examination, BEHAVIOR ANALYST CERTIFICATION BOARD ("BACB"), http://bacb.com/index.php?page=53 (last visited Jan. 1, 2011) [hereinafter Becoming Certified]. There are currently seventy-three certified ABA practitioners in Indiana. Certificant Registry Search Results [Search: Indiana], BACB, http://www.bacb.com/index.php? page=100155 (last visited Jan. 8, 2011).

106. See, e.g., Ind. Dep't Ins., Bull. 136, Insurance Coverage for Pervasive DEVELOPMENTAL DisORDERS, at 2 (Mar. 30, 2006), available at http://www.in.gov/idoi/files/Bulletin 136.pdf [hereinafter IND. BULL. 136]; LA ACT 648 TIP SHEET, supra note 103, at 2. 


\section{Consumer Protection Tools}

Insurers draft the insurance contract in such a way that they retain broad discretion over whether to approve or deny coverage. ${ }^{107}$ When an insurer denies coverage, the company is required to let the insured know the reason for the denial. ${ }^{108}$ To challenge a denied claim, the consumer can appeal through the company's internal grievance process. ${ }^{109}$ Indiana's Department of Insurance as said that the internal review, when related to ASD services, must be done by a physician with expertise in ASDs. ${ }^{110}$ Because the burden of proof lies with the consumer to show why the claim is a covered service, fighting a denial can be difficult and frustrating. ${ }^{111}$ If the consumer is still not satisfied after exhausting the company's internal grievance process, he or she may file a complaint with their state agency that regulates insurance or seek a remedy through the court system. ${ }^{112}$

In addition to licensing health insurers, states also regulate the insurers' finances, market conduct, policy forms, rules regarding access to coverage, required benefits, premiums, renewability, provider network arrangements, and consumer complaints. ${ }^{113}$ State insurance regulators can serve as intermediaries to resolve specific conflicts. ${ }^{114}$ In addition, state insurance regulating agencies can facilitate an external review by a panel of independent medical experts. ${ }^{115}$ However, the external review process may only be available for specific denials. ${ }^{116}$

State insurance regulators may create and enforce rules or develop guidelines for how insurance companies should interpret mandates. ${ }^{117}$ In 2006, nearly five years after the autism insurance mandate went into effect, the Indiana Department of Insurance issued a bulletin clarifying how insur-

107. Symposium, supra note 72 , at 107.

108. IND. BULL. 136, supra note 106, at 3.

109. Trivedi, supra note 86.

110. Ind. Bull. 136, supra note 106, at 1. See also, 215 Ill. Comp. Stat. AnN. 5/356z.14(g) (LexisNexis 2011) (requiring review by a physician with expertise in autism).

111. Symposium, supra note 72, at 107. See also, Redman, supra note 39.

112. See 40 Pa. Stat. ANN. $§ 764 \mathrm{~h}(\mathrm{k})(2)$ (West 2009); Bussey, 2000 U.S. Dist. LEXIS 658 , at $* 13$; Trivedi, supra note 86 .

113. Gary Claxton \& Janet lundy, How Private Health Coverage Works: A PRIMER: 2008 UPDATE 8 (The Kaiser Family Foundation 2008), available at http://www.kff.org/insurance/upload /7766.pdf.

114. Ind. Bull. 136, supra note 106, at 3; Colo. Rev. StAT. § 10-16-104(1.4)(h) (2010); LA ACT 648 TIP SHEET, supra note 103, at 2.

115. See 40 PA. StAT. AnN. $§ 764 \mathrm{~h}(\mathrm{k})(1)$ (West 2009) (noting that a covered individual is entitled to an expedited independent external review administered by the Pennsylvania Insurance Department); CLAXTON \& LUNDY, supra note 113, at 13.

116. Minutes, supra note 93; McHenry v. PacificSource Health Plans, CV-08-562-ST, 2010 U.S. Dist LEXIS 321, at *7 (D. Or. 2010) (noting the insured was not entitled to an external independent review because the claim was denied based on reasons other than medical necessity or experimental treatment).

117. Claxton \& Lundy, supra note 113, at 10. 
ance companies were to handle issues regarding the mandate. ${ }^{118}$ However, there can still be problems in relying on state agencies to deal with consumer complaints. For example, in California, a consumer advocacy group is suing the Department of Managed Health Care for allegedly permitting health insurers to deny coverage for ABA. ${ }^{119}$ While judicial review is available for state insurance regulator determinations, the high deference afforded to agency decisions makes it difficult to challenge in court. ${ }^{120}$

Lawsuits may also be brought under contract or tort law theories, such as fraud or bad faith, or under special state insurance laws. ${ }^{121}$ Typically, courts interpret insurance exclusions narrowly and coverage broadly. ${ }^{122}$ However, while courts may offer protection for consumers, the time, money, and resources needed to pursue litigation against an insurance company is not something many people can afford. ${ }^{123}$

To summarize, insurance companies have denied coverage to individuals with ASD under many different plan exclusions. The current process to challenge denials, while moderately successful, is time consuming and may be costly. One solution to the inadequate state-sponsored services and the insurance industry's treatment of autism gaining popular support is autism insurance reform.

\section{Autism Insurance Reform}

Mandates are laws that require state-licensed health insuring organizations to offer or include coverage for certain benefits or services. ${ }^{124}$ One of the latest state legislative trends is to enact a stand-alone autism insurance mandate that covers treatments specifically for ASDs. ${ }^{125}$ The ASD insurance mandate recognizes the demand for coverage of services to children with an ASD and attempts to eliminate previous benefit exclusions. ${ }^{126}$

Currently, twenty-three states require insurance coverage for the treatment of ASDs. ${ }^{127}$ Indiana enacted the first meaningful autism insur-

118. See InD. Bull. 136, supra note 106, at 1.

119. Victoria Colliver, State Agency Sued Over New Policy on Autism, S.F. Chronicle, July 1, 2009, http://articles.sfgate.com/2009-07-01/bay-area/17217191_1_autism-spectrumdisorder-treatment-decisions-health-policy; Consumer Watchdog et al v. Cal. Dep't of Managed Health Care, No. BS121397 (Cal. Super. Ct. Oct. 20, 2009).

120. In re Micheletti v. State Health Benefits Comm., 913 A.2d 842, 847 (N.J. Super. Ct. App. Div. 2007).

121. ClaXton \& Lundy, supra note 113 , at 13.

122. Wheeler v. Aetna Life Ins. Co., No. 01 C 60642003 U.S. Dist. LEXIS 12742, at *40 (N.D. Ill. July 21, 2003); In re Micheletti v. State Health Benefits Comm., 913 A.2d 842, 850-51 (N.J. Super. Ct. App. Div. 2007).

123. See Redman, supra note 39.

124. ClaXton \& Lundy, supra note 113, at 10.

125. Bunce \& Wieske, supra note 55 , at 1 .

126. Pennsylvania HB 1150, supra note 39 , at 35.

127. See supra note 7. 
ance mandate in 2001. ${ }^{128}$ It provides broad coverage for ASD services, and serves as a model for other states adopting autism insurance mandates. ${ }^{129}$

\section{Current State Autism Insurance Mandates - Common Provisions and Definitions}

The wording for autism insurance mandates is intentionally broad because ASD affects each person differently and requires individualized treatment. ${ }^{130}$ The various provisions for the different state statutes can be broken down into eight areas.

\section{a. Covered persons}

States vary on both the ages and diagnoses covered by the statute. Most states limit the age range for which coverage is required. ${ }^{131}$ Age limits typically cover the person through school age, but a few states restrict coverage to younger children. ${ }^{132}$ Currently, only Indiana, Massachusetts,

128. IND. CODE $\S 27-8-14.2$ (2009).

129. Katherine Kimball, Insuring a Future: Mandating Medical Insurance Coverage of Autism Related Treatments in Nebraska, 42 CREIGHTON L. ReV. 689, 690 (2009).

130. Trivedi, supra note 86.

131. ARIZ. Rev. Stat. ANN. $\S \S 20-826.04(D)(1)$, (2) (LexisNexis 2010) (requiring coverage of ABA for children under fifteen); CoLO. REV. STAT. § 10-16-104(1.4)(b)(I) (2010) (requiring coverage for children under nineteen); CONN. GEN. STAT. § 38a-514b(d) (2010) (requiring coverage of ABA for children under fifteen); FLA. STAT. $§ 627.6686(2)$ (c) (2010) (requiring coverage for children under eighteen, or over eighteen so long as the person is enrolled in high school); 215 ILL. COMP. STAT. ANN. 5/356z.14(a) (LexisNexis 2011) (requiring coverage for children under twenty-one); IowA CoDE $\S 514$ C.26(1) (West 2010) (requiring coverage for children under twenty-one); KAN. STAT. ANN. § 75-6524(a)(3) (2010) (requiring coverage for children under nineteen); Ky. REV. STAT. ANN. § 304.17A-142(1) (West 2010) (requiring coverage for children under twenty-one); LA. REV. STAT. ANN. $\S$ 22:1050(A)(1) (2009) (requiring coverage for children under seventeen); ME. REV. STAT. ANN. 24-A, § 2766(2) (2010) (requiring coverage for children five and under); Mo. ANN. STAT. § 376.1224(5) (West 2010) (requiring coverage for children eighteen and under for ABA); Mont. CoDE ANN. § 33-22-515(1) (2009) (requiring coverage for children eighteen and under); Nev. Rev. StAT. ANN. § 689B.0335 (LexisNexis 2010) (requiring coverage for children under eighteen, or until twenty-two so long as the person is enrolled in high school); N.H. Rev. StAT. ANN. § 417-E:2(III) (LexisNexis 2010) (requiring coverage for children under twenty-one for ABA); N.J. STAT. ANN. § 17B:27-46.1ii(c) (West 2009) (requiring coverage of ABA for children under twenty-one); N.M. STAT. AnN. § 59A-23-11(A) (LexisNexis 2009) (requiring coverage for children nineteen and under, or until twenty-two so long as the person is enrolled in high school); 40 PA. STAT. ANN. § 764h(a) (West 2009) (requiring coverage for children under twenty-one); S.C. CodE ANN. § 38-71-280(E) (2008) (requiring coverage for children under sixteen); TEX. INS. CODE ANN. § 1355.015(a) (West 2009) (requiring coverage for children ages three through five); VT. STAT. ANN. 8, § 4088i(a) (2010) (requiring coverage for ABA for children between eighteen months and six years old or through first grade, whichever comes first).

132. Me. Rev. StAt. AnN. 24-A, § 2766(2) (2010) (requiring coverage for children through age five); TEX. INS. CODE ANN. $§ 1355.015$ (a) (requiring coverage for children ages 
and Wisconsin do not have age limits for ASD treatment. ${ }^{133}$ Table 1 presents age limits by state under its autism insurance mandate.

Table 1. Age Limits for Coverage Under Autism Insurance Mandates by State St3 $^{134}$

\begin{tabular}{|l|l|}
\hline \multicolumn{1}{|c|}{ State } & Age Limit (in years) \\
\hline Arizona & $<15$ (for ABA) \\
\hline Colorado & $<19$ \\
\hline Connecticut & $<15$ (for ABA) \\
\hline Florida & $<18$ (or so long as enrolled in high school) \\
\hline Illinois & $<21$ \\
\hline Iowa & $<21$ \\
\hline Indiana & None \\
\hline Kansas & $<19$ \\
\hline Kentucky & $\leq 21$ \\
\hline Louisiana & $<17$ \\
\hline Maine & $\leq 5$ \\
\hline Massachusetts & None \\
\hline Missouri & $\leq 18$ (for ABA) \\
\hline Montana & $\leq 18$ \\
\hline Nevada & $<18$ (or $<22$ if enrolled in high school) \\
\hline New Hampshire & $<21$ (for ABA) \\
\hline New Jersey & $<21$ (for ABA) \\
\hline New Mexico & $\leq 19$ (or $\leq 22$ if enrolled in high school) \\
\hline Pennsylvania & $<21$ \\
\hline South Carolina & $<16$ \\
\hline Texas & $3-5$ \\
\hline Vermont & $2-6$ (or 1 ${ }^{\text {st }}$ grade, whichever comes first) \\
\hline Wisconsin & None \\
\hline
\end{tabular}

States may also limit the diagnoses covered under the mandate. While most tie the diagnostic eligibility to the Diagnostic and Statistical Manual of Mental Disorders ("DSM"), ${ }^{135}$ they may differ in the specific diagnoses

three through five); VT. STAT. ANN. 8, § 4088i(a) (2010) (requiring coverage for ABA for children between eighteen months and six years old or through first grade, whichever comes first).

133. Ind. Code § 27-8-14.2 (2009); Mass. Gen. Laws AnN. 32A, § 25 (West 2010); Wis. STAT. $§ 632.895(12 \mathrm{~m})$ (2009).

134. See supra note 131. It is important to note that with health care reform, limits previously held at twenty-one years old may be increased to twenty-six years old. See Mueller, supra note 40.

135. ARiz. Rev. Stat. Ann. $\S \S 20-826.04(E)(1)(a)-(c)$ (LexisNexis 2010); Colo. Rev. Stat. § 10-16-104(1.4)(a)(III) (2010); ConN. Gen. StAT. § 38a-514b(a)(3) (2010); Fla. STAT. § 627.6686(2)(b) (2010); 215 ILL. CoMP. STAT. ANN. 5/356z.14(i) (LexisNexis 2011); IOWA CODE § 514C.26(2)(c) (West 2010); Ind. Code § 27-8-14.2-3; Kan. STAT. ANN. § 756524(b)(2); Ky. Rev. Stat. Ann. § 304.17A-141(3) (West 2010); La. Rev. Stat. Ann. § 
that are covered. Some states cover all Pervasive Developmental Disorders ("PDDs"), ${ }^{136}$ whereas other states may limit coverage to ASDs. ${ }^{137}$ One state, New Hampshire, does not define the scope of its legislation other than "pervasive developmental disorder or autism.". 138

\section{b. Covered services}

Autism advocates argue that model legislation should include coverage for diagnosis and assessment, ABA therapy, speech, occupational, and physical therapy, psychological care, psychiatric care, and pharmaceutical care. $^{139}$ Indiana allows for broad coverage of ASD services, so long as those treatments are medically necessary and prescribed by a physician through a treatment plan. ${ }^{140}$ To combat the difficulty many families face in accessing $\mathrm{ABA}$ in particular, some states have mandated coverage just for ABA and therapeutic services. ${ }^{141}$ Many states further clarify that treatment specifically includes diagnosis, behavioral therapy (including ABA), prescription drug therapy, psychiatric care, psychological care, and therapeutic care (including speech, occupational, and physical therapy). ${ }^{142}$ However, plans that do not offer coverage for certain services to any member, like

22:1050(G)(3) (2009); Me. Rev. Stat. Ann. 24-A, § 2766(1)(B) (2010); Mass. Gen. Laws AnN. 32A, § 25(a) (West 2010); Mo. AnN. Stat. § 376.1224(1)(3) (West 2010); Mont. Code ANN. § 33-22-515(2) (2009); N.M. STAt. ANN. § 59A-23-11(H)(1) (LexisNexis 2009); 40 Pa. Stat. AnN. § 764h(f)(3) (West 2009); S.C. Code AnN. § 38-71-280(A)(1) (2008); VT. Stat. AnN. 8, § 4088i(d)(3) (2010).

136. Recall that PDDs include ASDs as well as Rett's disorder, and CDD. CONN. GEN. Stat. § 38a-514b(a)(3) (2010); Ind. Code § 27-8-14.2-3; Ky. Rev. StAT. AnN. § 304.17A141(3) (West 2010); LA. ReV. Stat. AnN. § 22:1050(G)(3) (2009); Me. ReV. Stat. AnN. 24A, § 2766(1)(B) (2010); Mass. Gen. Laws AnN. 32A, § 25(a) (West 2010); Mo. AnN. Stat. $\S 376.1224(1)(3)$ (West 2010); Nev. Rev. Stat. ANN. § 689B.0335(8)(b) (LexisNexis 2010) (LexisNexis 2009); N.M. Stat. AnN. § 59A-23-11(H)(1); 40 PA. StAT. AnN. § 764h(f)(3) (West 2009); VT. STAT. AnN. 8, § 4088i(d)(3).

137. Ariz. Rev. Stat. AnN. §§ 20-826.04(E)(1)(a)-(c) (LexisNexis 2010); Colo. Rev. STAT. § 10-16-104(1.4)(a)(III) (2010); FLA. STAT. §§ 627.6686(2)(b)(1)-(3) (2010); 215 ILL. COMP. StAT. AnN. 5/356z.14(i); IOWA CODE § 514C.26(2)(c) (West 2010); Kan. STAT. ANN. $\S 75-6524(b)(2)$ (2010); Mont. Code AnN. $\S \S 33-22-515(2)(a)-(c)$ (2009); S.C. Code AnN. $\S 38-71-280(\mathrm{~A})(1)$ (2008); WIS. STAT. § 632.895(12m)(a)(1) (2009).

138. N.H. Rev. Stat. ANN. § 417-E:2 (LexisNexis 2010).

139. Press Release, Autism Society of America, supra note 3.

140. IND. CODE § 27-8-14.2-4(a) (2010); IND. BuLL. 136, supra note 106, at 2 (noting that service exclusions that are inconsistent with the treatment plan will be considered invalid).

141. Ariz. Rev. Stat. AnN. § 20-826.04(A)(2) (LexisNexis 2010); Fla. Stat. § 627.6686(3)(b) (2010); N.J. STAT. ANN. § 17B:27-46.1ii(1)(a), (c) (West 2009) (limiting ABA coverage to autism only); N.M. STAT. AnN. § 59A-23-11(A)(2) (LexisNexis 2009); TEX. Ins. CODE ANN. § 1355.015(c)(1) (West 2009).

142. Colo. Rev. Stat. §§ 10-16-104(1.4)(a)(XII)(A)-(G) (2010); Conn. Gen. Stat. $\S \S$ 38a-514b(c)(A)-(G) (2010); Iowa Code AnN. § 514C.26(2)(j) (West 2010); Ky. Rev. StAT. ANN. § 304.17A-141(11) (West 2010); Mo. ANN. STAT. § 376.1224(1)(13) (West 2010); Nev. Rev. Stat. AnN. § 689B.0335(5) (LexisNexis 2010); 40 Pa. Stat. AnN. § 764h(f)(14) (West 2009); VT. Stat. AnN. 8, § 4088i(d)(9) (2010). 
prescription drug coverage, are not required to provide such services just for those members with ASD. ${ }^{143}$ Coverage of autism services may be subject to other general policy exclusions and limitations such as coordination of benefits, participating provider requirements, or prohibiting reimbursement for services provided by family or household members. ${ }^{144}$

To combat denials based on an insurer's determination that a treatment like ABA is experimental, several states have specifically defined the treatments listed in the statute as evidence-based. ${ }^{145}$ Further complicating matters, a few states have included language within their autism insurance reform legislation that reaffirms the state's obligation to provide services through early intervention programs and public schools while allowing insurers to exclude coverage for services received under IDEA laws when provided in the school context. However, insurers may still have to provide coverage for those services when done outside the classroom. ${ }^{146}$ The uncertainty between what constitutes special education, which would be covered by the schools under IDEA, and what constitutes medical therapy creates a grey zone that could result in children being denied coverage by both their school districts and their insurance companies. ${ }^{147}$

\section{c. Covered providers}

For quality control purposes, insurers require covered services to be rendered by qualified providers, who at a minimum are licensed in the state where they practice. ${ }^{148}$ However, ABA providers, while able to get national certification, are slow to be recognized or licensed within a state. ${ }^{149}$ Indeed,

143. Ind. Bull. 136, supra note 106, at 2; Colo. ReV. Stat. § 10-16104(1.4)(a)(XII)(D) (2010); Conn. Gen. Stat. § 38a-514b(c)(B) (2010); Me. Rev. Stat. ANN. 24-A, § 2766(2)(E) (2010); N.H. REv. StAT. ANN. § 417-E:2(I)(b) (LexisNexis 2010).

144. See, e.g., InD. Bull., supra note 106, at 2; N.M. STAT. AnN. § 59A-23-11(B)(4) (LexisNexis 2009); S.C. CodE ANN. § 38-71-280(C) (2008).

145. Ariz. Rev. Stat. AnN. § 20-826.04(E)(2) (LexisNexis 2010); Colo. Rev. Stat. § 10-16-104(1.4)(a)(XII) (2010); Conn. Gen. Stat. § 38a-514b(a)(4) (2010); Mont. Code ANN. § 33-22-515(3)(b)(i) (2009); Nev. Rev. StAT. ANN. § 689B.0335(8)(e) (LexisNexis 2010); Wis. StAT. $§ 632.895(12 \mathrm{~m})(\mathrm{a})(3)$ (2009).

146. Colo. Rev. Stat. § 10-16-104(1.4)(i); Conn. Gen. Stat. § 38a-514b(h)(2) (2010); Iowa Code § 514C.26(7) (West 2010); Ky. Rev. Stat. ANN. § 304.17A-142(8) (West 2010); Me. Rev. Stat. Ann. 24-A, § 2766(4) (2010); Mass. Gen. Laws Ann. 32A, § 25(f) (West 2010); Nev. Rev. Stat. AnN. § 689B.0335(7) (LexisNexis 2010); N.J. StAT. ANN. § 17B:27-46.1ii(1)(f) (West 2009); N.M. STAT. ANN. § 59A-23-11(B)(5) (LexisNexis 2009); 40 Pa. Stat. AnN. § 764h(d.1) (West 2009); Vt. Stat. AnN. 8, § 4088i(e) (2010).

147. See Mueller, supra note 40 (quoting a mother of a child with autism: "The insurance companies are telling us that therapy is educational . . . and the school district is telling us that its medical.").

148. Medical Policy, supra note 71, at 6. But see IND. Bull. 136, supra note 106, at 2 (noting that Indiana does not license ABA therapists but that it would be inappropriate for an insurer to deny a claim based on lack of license).

149. See supra section II. C. 2. b. (V). 
some autism insurance mandates do not specifically include certified ABA therapists as covered providers. ${ }^{150}$ To address this issue, some states allow nationally certified behavior therapists to provide treatment. ${ }^{151}$ Other states address the problem by creating a category of Autism Service Providers, which include $\mathrm{ABA}$ therapists and other providers with specific knowledge and experience with ASDs. ${ }^{152}$

\section{d. Treatment plans}

Several states require a treatment plan to be submitted to the insurance company. ${ }^{153}$ The treatment plan must include all elements necessary for the insurer to properly pay claims. ${ }^{154}$ These elements generally include the in-

150. See Ind. Code $§ 27-8-14.2$; Kan. Stat. AnN. $§ 75-6524$ (2010); N.J. StAT. AnN. § 17B:27-46.1ii (West 2009); N.M. STAT. AnN. § 59A-23-11(A); 40 PA. StAT. AnN. § 764h (West 2009); Tex. Ins. Code ANN. § 1355.015 (West 2009); Wis. STAT. § 632.895(12m).

151. ARiz. Rev. Stat. AnN. § 20-826.04(A)(2) (LexisNexis 2010); Conn. Gen. Stat. § 38a-514b(a)(4)(B)(i) (2010); FLA. STAT. $§ \quad 627.6686(3)(b)$ (2010); IOWA CODE $\S$ 514C.26(2)(b) (West 2010); Me. Rev. Stat. Ann. 24-A, § 2766(1)(C)(1) (2010); Mass. Gen. Laws Ann. 32A, § 25(a) (West 2010); Mo. AnN. Stat. § 376.1224(1)(2) (West 2010) (establishes a professional board within the state to license certified BCBAs); MONT. CODE AnN. § 33-22-515(3)(b)(ii) (2009); Nev. Rev. StAT. AnN. §§ 689B.0335(8)(g), (h) (LexisNexis 2010); N.H. Rev. Stat. AnN. § 417-E:2(I)(a) (LexisNexis 2010); 40 Pa. Stat. AnN. $\S 764 \mathrm{~h}(\mathrm{~g})(1)$ (West 2009).

152. Colo. Rev. Stat. § 10-16-104(1.4)(a)(II) (2010) (requiring Autism Service Providers to be licensed, certified, or registered by the state licensing board or by a nationally recognized organization, and to have at least one year of experience in working with people with ASDs); Conn. Gen. StAT. § 38a-514b(a)(2) (2010) (defining Autism Service Provider as any person, entity, or group that provides treatment for ASD); IOWA CoDE $\S$ 514C.26(2)(b) (West 2010) (defining Autism Service Provider as a nationally certified or licensed provider); Ky. Rev. Stat. AnN. § 304.17A-141(2) (West 2010) (creating a state licensing board for ABA therapists); LA. ReV. Stat. AnN. § 22:1050(G)(2) (2009); Mo. ANN. STAT. § 376.1224(1)(2) (West 2010) (defining Autism Service Provider as any licensed provider); Nev. Rev. StAT. ANN. § 689B.0335(8)(d) (LexisNexis 2010) (defining "certified autism behavior interventionist" as a person certified by the state board of psychological examiners and who is supervised by a licensed psychologist, behavior analyst, or assistant behavior analyst); 40 PA. STAT. ANN. § 764h(f)(2) (West 2009) (defining Autism Service Provider as a state licensed or certified person, entity, or group providing treatment of ASDs pursuant to a treatment plan); VT. STAT. ANN. 8, § 4088i(d)(2) (2010) (defining Autism Service Provider as any licensed or certified provider).

153. Colo. Rev. Stat. § 10-16-104(1.4)(a)(XIII) (2010); Conn. Gen. Stat. § 38a514b(c) (2010); FLA. STAT. § 627.6686(4)(a) (2010); IOWA CODE § 514C.26(2)(j) (West 2010); Ind. Code § 27-8-14.2-4(a) (2009); Mo. AnN. STAT. § 376.1224(4) (West 2010); N.J. Stat. ANN. § 17B:27-46.1ii(1)(d) (West 2009); N.M. Stat. AnN. § 59A-23-11(B)(1) (LexisNexis 2009); 40 PA. Stat. AnN. § 764h(f)(15) (West 2009); S.C. Code AnN. § 38-71280(B) (2008); Tex. Ins. Code Ann. § 1355.015(b) (West 2009). See also, 215 Ill. Comp. Stat. Ann. 5/356z.14(f) (LexisNexis 2011); Ky. ReV. Stat. Ann. § 304.17A-142(6)(c) (West 2010); MonT. CODE ANN. § 33-22-515(6) (2009) (allowing insurers to request a treatment plan when treatment is expected to require continued services); NEV. REv. STAT. ANN. § 689B.0335(5) (LexisNexis 2010); N.H. REV. STAT. ANN. § 417-E:2(II) (LexisNexis 2010) (stating that no treatment plan is required but the insurer may request one).

154. See Ind. Bull. 136, supra note 106, at 1; FlA. StAT. § 627.6686(7) (2010). 
dividual's diagnosis, a list of proposed treatments including: the frequency, duration, and likely outcomes for each; the frequency by which the treatment plan will be updated; and the treating physician's signature. ${ }^{155}$ The treatment plan allows several different professionally accepted therapies to address ASD symptoms without having to seek individual approval for each service. $^{156}$ States differ on who may develop and who must sign the treatment plan. Some states allow any qualified provider to develop and sign the treatment plan, ${ }^{157}$ while other states limit the task to only certain providers. ${ }^{158}$ Finally, a few states specifically require a physician to develop and sign the treatment plan. ${ }^{159}$ The insurance company has a right to periodically review the treatment plan to determine whether the services ordered are medically necessary. ${ }^{160}$ Some states condition the insurer's review process by requiring a specialist in the treatment of ASDs to review the plan. ${ }^{161}$ Even without requiring a formal treatment plan, some autism insurance mandates give the insurer the ability to conduct periodic reviews of whether a treatment continues to be medically necessary. ${ }^{162}$

155. See Ind. Bull. 136, supra note 106, at 2. Fla. Stat. $§ 627.6686(7) ; 215$ Ill. Comp. Stat. AnN. 5/356z.14(f) (LexisNexis 2011); N.J. StAT. AnN. § 17B:27-46.1ii(1)(d) (West 2009); N.M. Stat. AnN. § 59A-23-11(E) (LexisNexis 2009); S.C. Code AnN. § 3871-280(D) (2008).

156. Autism Speaks, Arguments, supra note 4, at 14.

157. Conn. Gen. STAT. § 38a-514b(C) (2010) (allowing physician, psychologist or social worker to develop a treatment plan); 215 Ill. COMP. STAT. ANN. 5/356z.14(f).

158. Colo. Rev. StAT. § 10-16-104(1.4)(a)(XIII) (2010); Iowa CodE $\S 514 C .26(2)(\mathrm{k})$ (West 2010) (requiring either a physician or clinical psychologist to sign the treatment plan); 40 PA. STAT. ANN. § 764h(f)(15) (West 2009) (requiring either a physician or clinical psychologist to sign the treatment plan).

159. Fla. Stat. § 627.6686(4)(a) (2010); Ind. CODE § 27-8-14.2-4(a) (2009); MonT. Code AnN. § 33-22-515(6) (2009); N.J. StAt. AnN. § 17B:27-46.1ii(1)(d) (West 2009); N.M. StAT. ANN. § 59A-23-11(E)(6) (LexisNexis 2009); Tex. Ins. CodE ANN. § 1355.015(b) (West 2009) (allowing only a physician to sign the treatment plan).

160. InD. Bull. 136, supra note 106, at 1; Colo. Rev. Stat. § 10-16-104(1.4)(h); Conn. Gen. Stat. § 38a-514b(f)(1) (2010); 215 Ill. Comp. Stat. Ann. 5/356z.14(f); IowA CODE § 514C.26(10) (West 2010); KAN. Stat. ANN. § 75-6524(a)(7)(A) (2010); LA. Rev. Stat. AnN. § 22:1050(F) (2009); Nev. Rev. Stat. AnN. § 689B.0335(5) (LexisNexis 2010); N.J. Stat. AnN. § 17B:27-46.1ii(1)(g) (West 2009); 40 PA. Stat. AnN. § 764h(i) (West 2009); S.C. CoDE ANN. § 38-71-280(C) (2008) (allowing insurers to review the treatment plan every six months or sooner if the treating physician agrees).

161. InD. Bull. 136, supra note 106, at 1; 215 Ill. Comp. Stat. AnN. 5/356z.14(g) (LexisNexis 2011) (stating that an expert in ASD is required only when challenging medical necessity). There is no standard definition of what makes someone an expert in ASDs, however, generally expertise is determined based on scope of practice and professional reputation.

162. KAN. STAT. ANN. § 75-6524(a)(7)(B) (2010) (stating that insurer may review and deny treatments based on medical necessity); Ky. Rev. Stat. AnN. § 304.17A-142(6)(a) (West 2010) (stating that insurer can request utilization review annually); ME. REv. StAT. ANN. 24-A, § 2766(2)(B) (2010) (stating that insurer may require the proscribing physician or psychologist to provide evidence of ongoing medical necessity). 


\section{e. Maximum benefit amounts}

Only a few states, Indiana, Massachusetts, Texas and Vermont, do not place maximum yearly benefit limits on ASD services. ${ }^{163}$ However, most states set an annual maximum benefit amount for ASD services; sometimes this limit just applies to ABA. ${ }^{164}$ Some states lower the yearly maximum benefit as the child gets older. ${ }^{165}$ For example, Arizona allows benefits up to $\$ 50,000$ per year for a child under the age of nine but decreases that amount to $\$ 25,000$ per year for a child ages nine to sixteen. ${ }^{166}$ This tiered approach emphasizes the need for early intensive therapy while constraining the overall costs associated with treating a child with an ASD. Table 2 presents a summary of maximum benefit amounts by state.

163. Ind. Code § 27-8-14.2 (2009); Mass. Gen. Laws AnN. 32A, § 25 (West 2010); Tex. Ins. Code AnN. § 1355.015 (West 2009); Vt. StAT. AnN. 8, § $4088 \mathrm{i}$ (2010).

164. ARIz. ReV. StAT. ANN. $\S \S 20-826.04(D)(1)$, (2) (LexisNexis 2010) (limiting ABA to $\$ 50,000$ per year up to age nine, $\$ 25,000$ per year for an eligible person aged nine to sixteen); Colo. Rev. Stat. § 10-16-104(1.4)(b)(I) (2010) (limiting ABA to $\$ 34,000$ per year for a child under nine, $\$ 12,000$ per year for a child aged nine to eighteen); CONN. GEN. STAT. $\S 38 \mathrm{a}-514 \mathrm{~b}$ (d) (2010) (limiting ABA therapy to $\$ 50,000$ per year for a child under nine, $\$ 35,000$ per year for a child between nine and twelve, $\$ 25,000$ per year for a child between thirteen and fourteen); FLA. STAT. § 627.6686(4)(b) (2010) (limiting ABA and therapeutic services to $\$ 36,000, \$ 200,000$ in total lifetime benefits); 215 ILl. Comp. Stat. AnN. $5 / 356 z .14$ (b) (LexisNexis 2011) (limiting benefits to $\$ 36,000$ per year); IowA CODE $\S$ 514C.26(3) (West 2010) (limiting coverage to $\$ 36,000$ per year); KAN. STAT. ANN. $\S \S 75-$ $6524(\mathrm{a})(3)$, (4) (2010) (limiting coverage to $\$ 36,00$ per year for children under seven and $\$ 27,000$ per year for children seven through nineteen); Ky. REV. STAT. AnN. §§ 304.17A142(2)(a), (b), -143(2) (West 2010) (limiting benefits to $\$ 50,000$ for children under seven and $\$ 1,000$ per month for children between seven and twenty-one for large group plans; $\$ 1,000$ per month for small group and individual plans); LA. REV. StAT. AnN. $\S$ 22:1050(D)(1) (2009) (limiting all ASD services to $\$ 36,000$ per year, $\$ 144,000$ in total lifetime benefits); ME. ReV. StAT. ANN. 24-A, § 2766(2)(D) (2010) (limiting benefits to $\$ 36,000$ per year for ABA); Mo. ANN. STAT. $\$ 376.1224(5)$ (West 2010) (limiting benefits to $\$ 40,000$ per year for ABA, but the limit may be exceeded upon a showing of medical necessity); Mont. CodE ANN. $\S \S 33-22-515(4)(a)(i)$, (ii) (2009) (limiting coverage to $\$ 50,000$ per year for children eight and under, $\$ 20,000$ per year for children nine through eighteen); NEV. Rev. Stat. ANN. § 689B.0335(2)(a) (LexisNexis 2010) (limiting ABA to $\$ 36,000$ per year); N.H. Rev. Stat. AnN. § 417-E:2(III) (LexisNexis 2010) (limiting benefits to $\$ 36,000$ per year for children twelve and under and $\$ 27,000$ per year for children thirteen through twenty-one years old); N.J. STAT. ANN. § 17B:27-46.1ii(1)(c)(3)(a) (West 2009) (limiting coverage to $\$ 36,000$ per year); N.M. STAT. ANN. § 59A-23-11(B)(2) (LexisNexis 2009) (limiting coverage to $\$ 36,000$ per year, $\$ 200,000$ in total lifetime benefits); 40 PA. STAT. ANN. $\S$ $764 \mathrm{~h}$ (b) (West 2009) (limiting coverage to $\$ 36,000$ per year); S.C. CODE ANN. § 38-71280(E) (2008) (limiting ABA to $\$ 50,000$ per year); WIS. STAT. $§ 632.895(12 \mathrm{~m})(\mathrm{b})(2009)$ (limiting intensive services like ABA and speech therapy to $\$ 50,000$ per year, $\$ 25,000$ limit on other ASD services). It is also important to note that with new health care reform laws, the maximum lifetime benefit limits may no longer be allowed. See Mueller, supra note 40.

165. See supra note 164: Arizona, Colorado, Connecticut, Kansas, Kentucky, Montana, New Hampshire.

166. Ariz. Rev. StAt. AnN. $\S \S 20-826.04(D)(1)$, (2) (LexisNexis 2010). 
Table 2. Maximum Benefit Amounts by State for ASD Services ${ }^{167}$

\begin{tabular}{|l|l|}
\hline \multicolumn{1}{|c|}{ State } & \multicolumn{1}{c|}{$\begin{array}{c}\text { Maximum Yearly Benefit Amount } \\
\text { Number in parentheses indicates age restrictions } \\
\text { associated with the amount. }\end{array}$} \\
$\begin{array}{l}\text { ABA indicates that limits are applied specifically to } \\
\text { ABA therapy }\end{array}$ \\
\hline Arizona & ABA: $\$ 50,000(<9) ; \$ 25,000(9-16)$ \\
\hline Colorado & ABA: $\$ 34,000(<9) ; \$ 12,000(9-18)$ \\
\hline Connecticut & ABA: $\$ 50,000(<9) ; \$ 35,000(9-12) ; \$ 25,000(13-14)$ \\
\hline Florida & ABA/Therapeutic services: $\$ 36,000$ \\
\hline Illinois & $\$ 36,000$ \\
\hline Iowa & $\$ 36,000$ \\
\hline Indiana & None \\
\hline Kansas & $\$ 36,000(<7) ; \$ 27,000(7-19)$ \\
\hline Kentucky & $\begin{array}{l}\$ 50,000(<7) ; \$ 1,000 \text { per month }(7-21) ; \$ 1,000 \text { per } \\
\text { month for small group and individual plans }\end{array}$ \\
\hline Louisiana & $\$ 36,000$ \\
\hline Maine & ABA: $\$ 36,000$ \\
\hline Massachusetts & None \\
\hline Missouri & $\begin{array}{l}\text { ABA: } \$ 40,000(\text { limit may be increased by medical ne- } \\
\text { cessity) }\end{array}$ \\
\hline Montana & $\$ 50,000(<8) ; \$ 20,000(9-18)$ \\
\hline Nevada & ABA: $\$ 36,000$ \\
\hline $\begin{array}{l}\text { New } \\
\text { Hampshire }\end{array}$ & $\$ 36,000(\leq 12) ; \$ 27,000(13-21)$ \\
\hline New Jersey & $\$ 36,000$ \\
\hline New Mexico & $\$ 36,000$ \\
\hline Pennsylvania & $\$ 36,000$ \\
\hline $\begin{array}{l}\text { South } \\
\text { Carolina }\end{array}$ & $\$ 50,000$ \\
\hline Texas & None \\
\hline Vermont & None \\
\hline Wisconsin & $\begin{array}{l}\text { ABA, speech therapy: } \$ 50,000 ; \$ 25,000 \text { for other ASD } \\
\text { services }\end{array}$ \\
\hline
\end{tabular}

\section{f. Prohibiting limits on the number of visits}

Due to the frequency of visits needed for intensive ABA and speech therapy, many states prohibit insurance companies from placing limits on the number of visits for ASD treatments. ${ }^{168}$ This is one instance where in-

167. See supra note 164.

168. Ind. Bull., supra note 106, at 2; Conn. Gen. StAT. § 38a-514b(e)(1) (2010); 215 
surers may be required to go beyond what they provide for other users of certain services. For example, where speech therapy may be limited to a certain number of sessions for illness in general, speech therapy visits for individuals with ASD may not be limited when the treatment is prescribed as medically necessary.

\section{g. Prohibiting termination or refusal to renew a policy}

As previously discussed, insurance companies may have blanket exclusions for ASDs. ${ }^{169}$ Most autism insurance mandates prohibit blanket exclusions by providing that, "an insurer may not deny or refuse to issue coverage on, refuse to contract with, or refuse to renew, refuse to reissue, or otherwise terminate or restrict coverage on an individual under an insurance policy solely because the individual is diagnosed with an ASD."170

\section{h. Types of insurance plans affected}

There are several mechanisms for accessing health insurance. By far the most common is through employer-sponsored plans. ${ }^{171}$ Two primary ways employers provide access to coverage is through self-funded plans or group benefit plans. Self-funded insurance policies are typically offered to employees by large companies or government employers. ${ }^{172}$ The employer pays the employees' health care costs from its own pocket and assumes the risk that it will be able to cover all its employees' health care needs. ${ }^{173} \mathrm{Be}-$ cause these self-funded plans are not actually insurance, states generally cannot regulate their content or activities and, therefore, cannot require them to offer any specified benefits. ${ }^{174}$ This means that states cannot re-

Ill. Comp. Stat. AnN. 5/356z.14(b) (LexisNexis 2011); Iowa CoDE $\S$ 514C.26(3) (West 2010); Kan. Stat. AnN. § 75-6524(b)(2) (2010); Ky. Rev. Stat. AnN. § 304.17A-142(3) (West 2010); La. Rev. Stat. Ann. § 22:1050(B) (2009); Me. Rev. Stat. Ann. 24-A, § 2766(2)(C) (2010); Mass. Gen. Laws Ann. 32A, § 25(e) (West 2010); Mo. Ann. Stat. § 376.1224(7) (West 2010); Nev. Rev. Stat. ANN. § 689B.0335(4) (LexisNexis 2010); N.J. STAT. ANN. § 17B:27-46.1ii(1)(c)(1) (West 2009) (prohibiting limits on visits for behavior intervention only); 40 PA. StAT. ANN. § 764h(b) (West 2009); VT. STAT. ANN. 8, § 4088i(b) (2010); Wis. STAT. § 632.895(12m)(b)(2) (2009).

169. See supra Part II.C.2.a.

170. Ariz. Rev. Stat. AnN. § 20-826.04(A)(1) (LexisNexis 2010); Colo. Rev. Stat. $\S \S 10-16-104(1.4)(d),(g)(2010)$; Fla. STAT. $§ 627.6686(6)$ (2010); 215 Ill. Comp. STAT. AnN. 5/356z.14(e) (West 2011); Ind. Code § 27-8-14.2-4(a) (2009); La. Rev. Stat. AnN. § 22:1050(A)(2) (2009); Nev. Rev. Stat. AnN. § 689B.0335(3)(b) (LexisNexis 2010); N.M. StAT. ANN. § 59A-23-11(D) (LexisNexis 2009); S.C. CodE ANN. § 38-71-280(B) (2008).

171. ClaXton \& Lundy, supra note 113, at 1.

172. Id. at 3.

173. Id.

174. Id. at 17. Self-funded plans are regulated by ERISA, which preempts state regulations. Despite not being required to comply with mandated coverage, several self-insured companies provide coverage for autism. See Information for Families with Self-Funded Health Insurance Plans, AUTISM SPEAKs, http:/www.autismvotes.org/site/ 
quire private self-funded plans to cover ASD services using a mandate. ${ }^{175}$ However, despite state employees' health plans often being self-funded, some states have extended the mandate to apply to state government employees and their dependents because the state has control over its own employees' coverage. ${ }^{176}$

Group benefit plans are typically purchased by an employer or group, such as an organization, union, or professional association. ${ }^{177}$ There are generally no enrollment exclusions within a group benefit plan, meaning anyone in the group may join. ${ }^{178}$ These plans are very common and are highly regulated by the states. ${ }^{179}$ In fact, nearly all autism insurance mandates apply to group policies. ${ }^{180}$ While regulated similar to large group plans, small groups of less than fifty members are exempt in some states from the ASD mandate. ${ }^{181}$

Because insurance regulation is left to the individual states, ${ }^{182}$ there is an unusual interaction between state laws when an employer is based in a state without an autism insurance mandate but has employees living in a state with an autism insurance mandate. For example, if a company uses an insurance plan covered by the law where it is headquartered, that state's insurance laws would govern, even if the company had employees working in Indiana. ${ }^{183}$ On the other hand, employees based in other states that work for a company headquartered in Indiana that uses an Indiana health insurance policy, would be covered by the mandate. ${ }^{184}$ Similarly, Missouri requires policies written outside of Missouri, but insuring Missouri residents,

c.frKNI3PCImE/b.5216011/k.1245/Selfinsured_Companies_and_Autism_Coverage.htm (last visited Jan. 8, 2011) (listing companies with self-insured health plans that have opted to provide coverage for autism therapies).

175. But see, Mo. AnN. Stat. § 376.1224(12)(2) (West 2010) (applying the mandate to self-insured group plans to the extent not preempted by federal law); MONT. CODE ANN. $\S$ 33-22-515(8) (2009) (applying the mandate to any self-funded program that is not regulated by ERISA.

176. Fla. Stat. § 627.6686(2)(d) (2010); Iowa Code § 514C.26(1) (West 2010); Kan. Stat. AnN. § 75-6524 (2010); MASs. Gen. LAws AnN. 32A, § 25 (West 2010); Mo. AnN. Stat. § 376.1224(12) (West 2010); Mont. Code AnN. § 33-22-515(8) (2009); Nev. Rev. StAT. ANN. § 287.0276 (LexisNexis 2010); N.J. StAT. ANN. §§ 17B:27-46.1ii(9), (10) (West 2009); S.C. Code ANN. § 38-71-280(A)(4) (2008); Vt. StAT. AnN. 8, § 4088i(d)(6) (2010).

177. ClaXton \& Lundy, supra note 113 , at 3.

178. Id. at 7 .

179. Id. at 9 .

180. See supra note 7. But see, Iowa CoDE $§ 514$ C.26(1) (West 2010) (requiring ASD coverage only for state-funded employee health plans); KAN. STAT. ANN. § 75-6524 (2010).

181. ARIz. Rev. Stat. AnN. § 20-826.04(B)(1) (LexisNexis 2010); Fla. Stat. § 627.6686(2)(d) (2010); LA. Rev. Stat. AnN. § 22:1050(H)(1) (2009); Mass. Gen. LAwS ANN. 32A, $\S 25(\mathrm{~g})$ (West 2010) (stating that small group employers can seek exemption if the mandate would increase their premium cost by more than $2.5 \%$ in a year); 40 PA. STAT. ANN. § 764h(e)(1) (West 2009); S.C. CoDE ANN. § 38-71-280(A)(4) (2008).

182. See ClAXTON \& Lundy, supra note 113 , at 8.

183. Trivedi, supra note 86.

184. Id. 
to provide ASD coverage. ${ }^{185}$ Therefore, employees of larger companies with locations nationwide may find it difficult to determine whether their health plan is covered by an ASD mandate, as the employee's state may differ from the company's headquartered state on ASD coverage.

When people do not have health insurance through their employer, they may purchase an individual health insurance policy. Individual policies are often more expensive because there is not an associated group to pool the risk. ${ }^{186}$ Like small-group plans, states will sometimes exempt individual plans from the ASD mandate. ${ }^{187}$ However, a few states require insurers selling individual policies to offer the option to include coverage for ASD using a rider, which allows the consumer to purchase the coverage as an option with a corresponding increase in premiums. ${ }^{188}$ Table 3 presents a summary of plans covered by autism insurance mandates.

Table 3. Plans Covered by Autism Insurance Mandate by State ${ }^{189}$

\begin{tabular}{|c|c|c|c|c|c|c|c|}
\hline State & 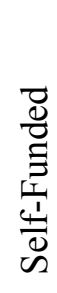 & 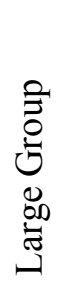 & 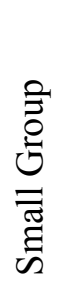 & 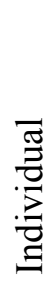 & $\stackrel{0}{\underline{I}}$ & 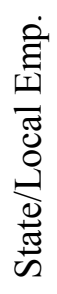 & 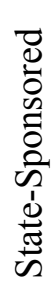 \\
\hline Arizona & $\mathrm{N}$ & $\mathrm{Y}$ & $\mathrm{N}$ & $\mathrm{N}$ & & & \\
\hline Colorado & $\mathrm{N}$ & $\mathrm{Y}$ & $\mathrm{Y}$ & $\mathrm{N}$ & $\mathrm{Y}$ & & \\
\hline Connecticut & & $\mathrm{Y}$ & $\mathrm{Y}$ & & & & \\
\hline Florida & & $\mathrm{Y}$ & $\mathrm{N}$ & $\mathrm{N}$ & & $\mathrm{Y}$ & \\
\hline
\end{tabular}

185. Mo. AnN. Stat. § 376.1224(2) (West 2010).

186. ClaXton \& Lundy, supra note 113 , at 6.

187. Ariz. Rev. Stat. AnN. § 20-826.04(B)(1) (LexisNexis 2010); Colo. Rev. Stat. § 10-16-104(1.4)(a)(IV) (2010) (individual policies not required to provide coverage but if the individual policy covers autism, it must follow the mandate); FLA. STAT. § 627.6686(2)(d) (2010); La. Rev. Stat. AnN. § 22:1050(H)(2) (2009); S.C. Code AnN. § 38-71-280(A)(4) (2008).

188. Ind. CODE § 27-8-14.2-5(a) (2009); Mo. AnN. STAT. § 376.1224(13) (West 2010); Nev. Rev. StAT. AnN. § 689A.0435 (LexisNexis 2010).

189. As definitions of insurance plans may vary slightly by state, readers are encouraged to visit their state's insurance regulatory body to determine what types of plans are available and to confirm whether their particular plan is covered by the mandate. This table serves merely as a broad overview. "Small Group" refers to plans with less than fifty enrollees, "State-Sponsored" refers to state sponsored health insurance programs like Children's Health Insurance Programs ("CHIP") or expansion to Medicaid coverage. Arizona's statute applies to group insurance provided by a hospital or medical service corporation plan. Kansas' legislature is studying the effect of the mandate on state employee plans before determining whether it should be expanded to private insurers. KAN. STAT. ANN. § 75-6524(c)(2). Texas requires state mandated plans to cover ASD treatments, and it is unclear which specific plans will be covered. 


\begin{tabular}{|c|c|c|c|c|c|c|c|}
\hline State & 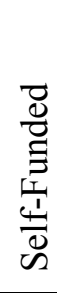 & 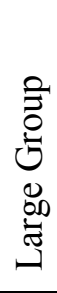 & 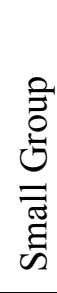 & 胥 & $\sum_{\underline{I}}^{\varrho}$ & 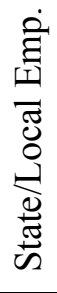 & 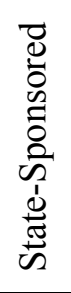 \\
\hline Illinois & & $\mathrm{Y}$ & $\mathrm{Y}$ & $\mathrm{Y}$ & $\mathrm{Y}$ & & \\
\hline Iowa & & & & $\mathrm{N}$ & & $\mathrm{Y}$ & \\
\hline Indiana & & $\mathrm{Y}$ & $\mathrm{Y}$ & $\mathrm{Y}$ & $\mathrm{Y}$ & & \\
\hline Kansas & & & & & & $Y$ & \\
\hline Kentucky & & Y & Y & Y & & & \\
\hline Louisiana & & $\bar{Y}$ & $\mathrm{~N}$ & $\mathrm{~N}$ & Y & & \\
\hline Maine & & $\mathrm{Y}$ & Y & $\mathrm{Y}$ & & & \\
\hline Massachusetts & & $\mathrm{Y}$ & $\mathrm{Y}$ & & Y & $\mathrm{Y}$ & \\
\hline Missouri & $\mathrm{Y}$ & $\mathrm{Y}$ & $\mathrm{Y}$ & Y & & $\mathrm{Y}$ & $\mathrm{N}$ \\
\hline Montana & $\mathrm{Y}$ & $\mathrm{Y}$ & $\mathrm{Y}$ & & & $\mathrm{Y}$ & \\
\hline Nevada & & $\mathrm{Y}$ & $\mathrm{Y}$ & $\mathrm{Y}$ & Y & $\mathrm{Y}$ & \\
\hline New Hampshire & & $\mathrm{Y}$ & $\mathrm{Y}$ & $\mathrm{Y}$ & & & \\
\hline New Jersey & & $\mathrm{Y}$ & $\mathrm{Y}$ & $\mathrm{a}$ & & & \\
\hline New Mexico & & $\mathrm{Y}$ & $\mathrm{Y}$ & $\mathrm{Y}$ & & & \\
\hline Pennsylvania & & $\mathrm{Y}$ & $\mathrm{N}$ & & & $\mathrm{Y}$ & $\mathrm{Y}$ \\
\hline South Carolina & & $\mathrm{Y}$ & $\mathrm{N}$ & $\mathrm{N}$ & $\mathrm{Y}$ & $\mathrm{Y}$ & \\
\hline Texas & & - & $\mathrm{N}$ & - & & & \\
\hline Vermont & & $\mathrm{Y}$ & $\mathrm{Y}$ & $\mathrm{Y}$ & $\mathrm{Y}$ & $\mathrm{Y}$ & $\mathrm{Y}$ \\
\hline Wisconsin & & $\mathrm{Y}$ & $\mathrm{Y}$ & $\mathrm{Y}$ & & $\mathrm{Y}$ & \\
\hline
\end{tabular}

\section{Autism Treatment Acceleration Act of 2009 (“ATAA”)}

The Autism Treatment Acceleration Act of 2009 ("ATAA"), if enacted as proposed, would require both self-insured group plans and individual health plans to provide coverage for the diagnosis and treatment of ASDs. ${ }^{190}$ Further, ATAA would require every state to mandate coverage for ASDs. ${ }^{191}$ Current ASD mandate statutes that do not meet the minimum set by the ATAA may be preempted and the ATAA will govern. ${ }^{192}$ How-

190. ATAA, S. 819, 111 th Cong. $§ 12$ (2009) (amending ERISA 29 U.S.C. 1185). The bill stalled in committee. However, for purposes of analysis, this note addresses the general text and spirit of the bill since it is possible that the bill could be reintroduced in the next session.

191. ATAA, S. 819, 111th Cong. § 12 (2009).

192. It is unclear how the ATAA will preempt state statutes, either in total or by provi- 
ever, states with autism insurance mandates that meet the standards set out in the ATAA will not be preempted. ${ }^{193}$

Similar to Indiana's mandate, the ATAA does not have age restrictions or maximum benefit amounts. ${ }^{194}$ Interestingly, the ATAA does not tie diagnostic eligibility to the DSM, and it includes all PDDs for the section amending ERISA but only ASDs for the section amending PHSA. ${ }^{195}$ The ATAA does not require a treatment plan and allows a wide range of professionals to order treatment, so long as the treatment is medically necessary. ${ }^{196}$ The ATAA lists several covered services, including diagnosis, ABA, pharmacy care, psychological and psychiatric care, and therapeutic care. $^{197}$ The ATAA prohibits covered plans from denying coverage on the basis that the service is necessary to develop, maintain, or restore skills or functioning or to prevent loss of skills or functioning. ${ }^{198}$ State, local, and tribal government health plans would generally be covered by the ATAA. ${ }^{199}$ However, a state, local, or tribal government employer that provided its employees with self-funded health plan coverage could opt out of the ATAA's requirements, just as self-funded state, local, and tribal government health plans can opt out of other federal insurance mandates. ${ }^{200}$

\section{E. Controversies and ASD Insurance Reform}

Underlying the push for ASD insurance reform is a debate among autism advocates, the state, and the insurance industry regarding who should pay for ASD services, and what the real impact of an ASD mandate will be.

\section{Who Should Pay for ASD Services?}

Opponents of autism insurance reform suggest that the autism insurance mandate is an attempt by the state to shift costs to private insurers. ${ }^{201}$

sion.

193. ATAA, S. 819, 111th Cong. § 12(e)(1) (2009).

194. Compare IND. CODE $\S 27-8-14.2$ (2009), with ATAA, S. 819, 111 th Cong. $\S 12$ (2009).

195. ATAA, S. 819, 111 th Cong. § 12(a)(f)(1) (2009).

196. ATAA, S. 819, 111th Cong. § 12(a)(f)(3) (2009) (defining treatments as services prescribed, provided, or ordered by a physician, psychologist, or other qualified professional who determines the care to be medically necessary).

197. ATAA, S. 819, 111 th Cong. $\S \S 12(a)(f)(2),(3)(A)-(E)(2009)$.

198. ATAA, S. 819, 111 th Cong. $\S 12$ (2009).

199. ATAA, S. 819, 111th Cong. § 12(b) (2009) (amending Public Health Service Act ("PHSA") 42 U.S.C. 300gg-4).

200. The Autism Treatment Acceleration Act (ATAA) Insurance Provision (S. 819, Section 12): Potential Autism Community Issues and Autism Speaks Response, Autism SPEAKS, at 2 (2009), http://www.autismvotes.org/atf/cf/\%7B2A179B73-96E2-44C3-88161B1C0BE5334B\%7D/FACT\% 20SHEET\%20-\%20ATAA\%20Insurance\%20Provision.pdf (last visited Jan. 10, 2011) [hereinafter Autism Speaks, Response].

201. Pennsylvania HB 1150, supra note 39, at 36. 
Historically, the state carried the burden of providing services like ABA and speech therapy through early intervention and school programs. ${ }^{202} \mathrm{~A}$ mandate is not justified, opponents argue, when coverage for services are already available. ${ }^{203}$ Concerning ABA therapy, opponents of insurance reform argue that $\mathrm{ABA}$ is more accurately described as educational and should, therefore, be provided by the schools. ${ }^{204}$ Supporters for ASD insurance reform point to the inadequacies of the public education system in dealing with children with ASDs. ${ }^{205}$ IDEA, the law guaranteeing a free and appropriate public education for children with disabilities, has historically failed to produce the statute's maximum funding provided to states, forcing public schools across the nation to absorb $\$ 381.8$ billion in special education costs that are left unfunded. ${ }^{206}$ Therefore, supporters of insurance reform argue that reliance on the education system to treat individuals with an ASD places an unmanageable burden on a school's finances. ${ }^{207}$ Supporters for ASD insurance reform suggest that without private insurance coverage, treatment is simply not going to happen. ${ }^{208}$

Still, opponents of autism insurance reform argue that the fix should be with the education system, not by shifting the cost to private insurers. ${ }^{209}$ The Center for Affordable Health Insurance notes that, "[i]f legislators want to help these families, they could go beyond the IDEA scope and create programs that do just that and fund them from general revenues rather than try to force those costs onto health insurance, which will just increase others' premiums." 210

In supporting the role of insurance coverage for ASD services, advocates often compare treatment for ASDs to treatment for other chronic illnesses typically covered by health insurance. ${ }^{211}$ ASD services focus on controlling or diminishing symptoms and other associated impairments. In this way, supporters of insurance reform argue that ASDs do not differ from numerous other chronic medical disorders, like hypertension, diabetes, or asthma, for which health insurance routinely covers treatment. ${ }^{212}$ Advocates also point to the status of the provider giving the diagnosis as an argument in favor of health insurance coverage. Supporters argue that since a

202. See supra Part II.B.1.

203. PenNSYlVANIA HB 1150, supra note 39 , at 10.

204. See Bunce \& Wieske, supra note 55, at 1.

205. Kimball, supra note 129, at 690.

206. Id. at 715-16.

207. Id. at 690 .

208. See generally Autism Speaks, Arguments, supra note 4 (discussing the need for ASD insurance reform).

209. Bunce \& Wieske, supra note 87 , at 1 .

210. Victoria Bunce \& JP Wieske, Health Insurance Mandates in the States 20092 (The Council for Affordable Health Insurance 2009), at 2.

211. Press Release, Autism Society of America, supra note 3.

212. PenNSYlvania HB 1150, supra note 39, at 4. 
medical doctor or a clinical psychologist diagnoses ASDs and those providers prescribe treatment, ASDs should be considered medical conditions covered by health insurance. ${ }^{213}$

\section{Financial Impact of ASD Insurance Reform}

The debate about whether health insurance should ultimately be responsible for covering the cost of ASD treatments or whether states should reform their service delivery systems will continue. However, the reality concerning an ASD mandate's effect on premiums is not something legislators can easily ignore. While ABA is an expensive treatment, many argue that failure to provide such treatment would result in greater long-term societal costs. ${ }^{214}$ In response, opponents argue that the premium increase required to pay for this added coverage could force more people to drop insurance coverage, which may also result in increased societal costs. ${ }^{215}$ Balancing the long-term savings to taxpayers against the immediate impact on premium rates is not easy for a legislator to do when faced with angry voters on both sides of the controversy.

Supporters of autism insurance reform point to the estimated cost saving to taxpayers through reduced use of state-sponsored social services across the individual's lifespan. ${ }^{216}$ The estimated cost of providing statesponsored services is extraordinary and decreases resources available to address the needs of other citizens. ${ }^{217}$ While early behavioral intervention does not guarantee success for all, it does decrease the likelihood that individuals with ASD will need prolonged care throughout their life. ${ }^{218}$ Lack of early intervention limits the number of individuals with ASD who are able to achieve higher levels of functioning; thus, indirectly affecting public schools and Medicaid services, which are required to provide specialized education and more intense psychiatric treatment. ${ }^{219}$

Beginning with the first autism insurance mandate enacted in 2001, states have come to realize the long-term benefits of requiring insurance carriers to cover ASD services. For example, the Pennsylvania Commonwealth Insurance Department estimated that Medicaid could save \$16.5 to $\$ 22.2$ million in the first year following the adoption of ASD insurance reform. ${ }^{220}$ In contrast, funds once spent on services for ASD may be merely

213. Press Release, Autism Society of America, supra note 3.

214. Autism Speaks, Arguments, supra note 4, at 16.

215. BUNCE \& WIESKE, supra note 210 , at 3.

216. Autism Speaks, Arguments, supra note 4, at 16.

217. Pennsylvania HB 1150, supra note 39, at 26.

218. Id. at 24 .

219. Id. at 23-24.

220. Id. at 26 . 
shuffled into another funding category, leaving taxpayers without a reduction in spending.

ASD insurance reform supporters even suggest that mandates can save insurance providers money. Mandated services that are preventive in nature can mitigate other long-term health costs, thereby justifying the initial cost of the mandate. ${ }^{221}$ For example, the use of ABA can save insurance companies money over time by reducing the need for expensive inpatient hospitalizations. $^{222}$

On the other hand, while mandates make health insurance more comprehensive, mandates also make it more expensive, as insurers must now pay for care consumers previously funded out of their own pockets. ${ }^{223}$ Like states, insurance companies are concerned about the rapid increase in the number of individuals with ASD and how that will affect the companies' ability to keep premiums affordable. ${ }^{224}$ ASD insurance reform is estimated to add approximately one percent to premium costs. ${ }^{225}$ The Indiana Legislative Services Agency estimates that Indiana's ASD mandate increases premiums by $\$ 0.44$ to $\$ 1.67$ per member per month. ${ }^{226}$ Advocates argue that for only a modest effect on premiums, ASD insurance reform holds the promise of significantly improving the lives of thousands of children. ${ }^{227}$ As an additional guard against rapid premium increases following introduction of an ASD insurance mandate, Massachusetts allows insurers, corporations, or HMOs to seek exemption from the requirement to cover ABA for three years if the entity can show that including the treatment would exceed one percent of the premiums charged. ${ }^{228}$ Following the three year period, the entity would be required to cover ABA. ${ }^{229}$ While a program like this delays the availability of ABA for families, it would allow the entity to gradually increase its premiums across a three year time span, rather than increasing premiums in one large lump sum.

Insurers argue that the problem is not just with the autism mandate, but includes the accumulated effects of multiple mandates that price many people out of the market. ${ }^{230}$ The number of mandates differs by state. Idaho has the lowest number of mandates at thirteen; Rhode Island has highest

221. Id. at 42 .

222. Id. at 38 .

223. BUNCE \& WIESKE, supra note 223 , at 1 .

224. Id. at 3 .

225. Id. at 5; PenNSYlVANIA HB 1150, supra note 39, at 43.

226. Ind. Leg. Serv. Agency, Fiscal Impact Statement LS 6861, Insurance COVERAGE FOR AUTISM 3 (2001), available at http://www.in.gov/legislative/bills/2001/PDF/ FISCAL/HB1122.006.pdf.

227. Autism Speaks, ARguments, supra note 4, at 15.

228. MASS. GEN. LAWS ANN. 32A, § 25(g) (West 2010)

229. MASs. Gen. LAws AnN. 32A, § 25(g)(2) (West 2010).

230. BunCE \& WIESKE, supra note 210, at 2. 
at seventy, whereas Indiana has thirty-four mandates. ${ }^{231}$ The insurance industry lobby notes that mandates require insurers to pay more claims, and eventually they must raise premiums to cover those costs. ${ }^{232}$ Opponents argue that mandated benefits increase the cost of basic health coverage from twenty to fifty percent, depending on the number of mandates, the benefit design, and the cost of the initial premium. ${ }^{233}$ That additional cost may be the determining factor in whether or not a person can afford health insurance. $^{234}$ When health insurance costs increase, more people, especially healthy people, drop or decline coverage leading to adverse selection. ${ }^{235}$ Adverse selection occurs when less healthy people disproportionately enroll in a risk pool with a low number of healthy people. ${ }^{236}$ Therefore, mandates that drive up the cost of health insurance may lead younger and healthier people to cancel their coverage, leaving the pool smaller and sicker. ${ }^{237}$

To summarize, the main controversies surrounding ASD insurance reforms focus on who should be financially responsible for providing services to individuals with ASD. While both states and insures recognize the benefits of ASD services, neither wants to be responsible for their enormous cost. States, looking to reap the benefits of long-term savings to public services, have shifted the responsibility to private insurers through ASD insurance reform. But is ASD insurance reform working?

\section{ANALYSIS}

\section{A. ASD Insurance Mandates}

Even though insurance mandates help address some of the ways insurers deny coverage for ASD treatments, the problems persist. Since many ASD insurance mandates are just being implemented, there is not much data available on how well the mandates are working to ensure access to services for individuals with ASD. Kansas and Missouri have built in to their legislation requirements for ongoing study of the effects of autism mandates on quality of services, associated costs through increased premiums, and savings realized by tax-payer funded programs. ${ }^{238}$ More states should en-

231. Id. at 4 .

232. See Gail A. Jensen \& Michael A. Morrisey, Mandated Benefit Laws and EMPloyer-SpOnsored HeAlth InSURAnCE 12 (Health Ins. Ass'n of Am. 1999).

233. BUNCE \& WIESKE, supra note 210 , at 1.

234. Council For AfFordable Health Insurance ("CAHI”), 2009 SATE Legislators' Guide to HeAlth Insurance Solutions (2009), available at http://www.cahi.org/cahi_contents/ resources/pdf/StateLegGuide2009.pdf; PENNSYLVANIA HB 1150, supra note 39, at 27.

235. ClaXTON \& LUNDY, supra note 113, at 6.

236. $I d$.

237. Bunce \& Wieske, supra note 55 , at 1 .

238. KAN. StAT. ANN. § 75-6524(c) (2010) (stating that a study will be used to deter- 
courage the collection and analysis of this type of information because without this information, one cannot adequately determine the effect these mandates have on both the families of children with ASDs as well as the cost to the general public. However, based on the common provisions discussed above, several issues may pose problems as consumers request services covered under ASD insurance reform measures.

\section{Covered Persons}

$$
\text { a. Age }
$$

Both Florida and South Carolina require a diagnosis prior to a certain age to qualify for ASD benefits. ${ }^{239}$ Restricting the age for when a child must be diagnosed places a burden on families to seek a diagnosis quickly. This requires families to be cognizant of any developmental delays in their child and be motivated enough to seek assistance from a doctor. Moreover, it requires primary care physicians to acknowledge the parents' concerns and make appropriate and timely referrals to specialists, who may have lengthy waiting lists. For individuals with Asperger's syndrome, who generally receive a diagnosis later in childhood, baseline age restrictions have the potential to exclude them completely from mandated benefits.

Early detection and intervention are critical to the ultimate functioning level of people with ASDs. However, ASD mandates that cap the age at which benefits may be received ignore the continuing challenges faced by individuals with ASD. ${ }^{240}$ The National Institute of Child Health and $\mathrm{Hu}-$ man Development notes that, "[i]t is never too late to benefit from treatment. People of all ages with ASDs at all levels of ability generally respond positively to well-designed interventions." 241 Costs are an important consideration, and restricting the age for which ASD mandates apply is one way to reduce costs. However, states should be aware of the potential societal costs associated with denying coverage to older adolescents and adults with ASD compared to any immediate cost savings realized with age restrictions.

\section{b. Diagnosis}

Several states restrict the diagnoses covered under their mandate to

mine whether the mandate should be expanded to private insurance plans); Mo. ANN. STAT. $\S 376.1224(19)$ (West 2010).

239. Fla. Stat. § 627.6686(2)(c) (2010); S.C. CodE ANN. § 38-71-280(E) (2008) (requiring a diagnosis by eight years old).

240. It is important to note that with recent health care reform, the limits for all policies may be increased to include individuals up to age twenty-six. See Mueller, supra note 40.

241. NIH PUB No. 05-5592, supra note 28. 
ASDs only. ${ }^{242}$ While most states tie coverage to the most current edition of the DSM, other states either tie coverage to a specific edition of the DSM or do not tie coverage to the DSM at all. ${ }^{243}$ Indeed, the ATAA language as it stands does not relate eligibility to the DSM. ${ }^{244}$ The next edition of the DSM is set to for release in 2012 and will likely reflect a dramatic shift in diagnostic conceptualization. ${ }^{245}$ Disorders like Asperger's syndrome and PDD-NOS will cease to exist as independent disorders but will instead be covered under the broader designation, Autism Spectrum Disorders. ${ }^{246}$ It is unclear how this change will affect statutes tied to current DSM diagnostic categories. For statutes that limit coverage to only certain diagnoses but tie the definition to the current version of the DSM, the change has the potential to broaden the scope of individuals covered under the mandate. However, statutes that list covered diagnoses but do not tie coverage to the DSM risk confusion as diagnoses like PDD-NOS and Asperger's syndrome fade from use. Finally, statutes that refer to diagnoses in a specific edition of the DSM risk confusion in determining whether individuals diagnosed under the new diagnostic criteria fit the old definitions referenced in the statute. It is unclear whether insurers would deny coverage based on an old diagnosis, require a new diagnosis using new criteria, or challenge the applicability of the mandate to a class of people previously not covered. To avoid these problems, legislators should amend autism insurance reform legislation definitions to cover both the old diagnoses as well as the new. ${ }^{247}$ Furthermore, state insurance regulating agencies should be encouraged to develop appropriate guidelines and to collaborate with both providers and insurers to ensure that transition to a new diagnostic system does not disrupt services.

\section{Covered Services}

Compared to other disorders, research into treatments for ASD is in its infancy. Fortunately, most ASD mandates specifically outline what treatments are to be covered, thereby reducing the likelihood of those services

242. See supra note 137.

243. See supra note 135.

244. ATAA, S. 819, 111th Cong. § 12(a)(f)(1) (2009).

245. 299.00 Autistic Disorder, supra note 9.

246. Id. (reflecting the colloquial understanding of the relationship among the included disorders and expanding the spectrum to include CDD).

247. For example, the following language could be used where the list of inclusive diagnoses could be modified to include only those populations intended by the legislature to be covered under the mandate: "Autism Spectrum Disorders means any of the following disorders as defined by the DSM edition in force when the diagnosis was made: Autistic disorder, Asperger's syndrome, Pervasive Developmental Disorder, Not Otherwise Specified (PDDNOS), Childhood Disintegrative Disorder (CDD), Rett's Disorder, or Autism Spectrum Disorder (ASD)." 
being denied as experimental, educational, or habilitative. ${ }^{248}$ However, without a provision that allows the potential for new treatment modalities, it is possible the mandate could ultimately end up restricting services available to individuals with ASD. One solution is to broaden the covered treatments to include any evidence-based treatment prescribed in a treatment plan. ${ }^{249}$ However, a broad provision, like the one used in Indiana's mandate, would need support with strong interpretive guidelines from the state's insurance regulating agency outlining which treatments are considered evidence-based. ${ }^{250}$ Currently, there is an effort to include certain services, like ABA, as "essential benefits" for the purpose of the newly enacted health care reform law. ${ }^{251}$

\section{Covered Providers}

While a licensed clinician may supervise the development of an ABA program or assessment of a child's progress, unlicensed individuals typically provide the bulk of ABA services. Many health insurance benefit contracts only provide coverage for services rendered by licensed clinicians ${ }^{252}$ and states cannot force insurers to pay for services provided by unlicensed providers. ${ }^{253}$ While there is national certification available for ABA therapists at both the supervisor and direct therapist levels, ${ }^{254}$ many states do not yet recognize these individuals for state licensing purposes. ${ }^{255}$ A lack of recognition for nationally credentialed $\mathrm{ABA}$ therapists severely restricts the number of qualified providers available, which in turn drives up the demand and cost for those providers. ${ }^{256}$

Granting a state license to those with only the national ABA credentials would accomplish three main goals toward reducing the cost of ABA. First, it would ensure that there is state oversight and quality control, which would keep unqualified people from rendering services and provide con-

248. See supra note 141 and accompanying text.

249. See InD. Code $\S 27-8-14.2-4$ (a) (2009); Ind. Bull. 136, supra note 106, at 2. See also Colo. Rev. Stat. § 10-16-104(1.4)(a)(XII) (2010); Vt. Stat. ANN. 8, § 4088i(d)(7) (2010) (giving "medically necessary" a broad definition).

250. See InD. Bull. 136, supra note 106.

251. Shaun Heasley, Pressure Mounts to Include Special Needs Benefits in Insurance Coverage, Disability SCOOP (Oct. 26, 2010), http://www.disabilityscoop.com/2010/10 /26/special-needs-insurance/10894/ ("When health care reform legislation takes full effect in 2014 , insurers will be required to offer certain minimum benefits . . . What qualifies as an 'essential benefit' is currently being determined by the Department of Health and Human Services.").

252. See, e.g., Medical Policy, supra note 71.

253. See, e.g., LA ACT 648 TIP SHEET, supra note 103; Minutes, supra note 93, at 6.

254. Becoming Certified, supra note 105.

255. IND. BULL. 136, supra note 106, at 2; LA ACT 648 TIP SHEET, supra note 103.

256. For example, there are only seventy-three certified ABA practitioners in Indiana. Certificant Registry Search Results, supra note 105. 
sumer protection. Second, recognition of national certification would encourage more people to become therapists. This would allow market forces to reduce the costs of ABA through the increased availability of providers and competition. Finally, once ABA therapists attain qualified provider status, insurers would be able to bargain for reduced rates by including those providers in their network.

Even when a state does not recognize ABA therapists for state licensing purposes, there are ways to ensure treatment is not being denied due to the lack of a credentialed provider. For example, the Indiana Department of Insurance has said that despite its lack of state recognition for ABA therapists, "It is . . . inappropriate at this time for an insurer to deny a claim based upon the fact that the provider of ABA does not hold a license."257 Indeed, in the absence of state licensing, allowing insurers to deny claims based on a lack of state licensure would allow insurers to avoid paying for ABA altogether. ${ }^{258}$

One unique solution gaining popularity is the concept of Autism Service Providers. $^{259}$ This approach allows states to define the appropriate scope of professionals, licensed or not, who are qualified to provide services to individuals with ASD. This ensures not only a certain level of oversight by the state, but also recognizes the importance of having providers who are trained and experienced in the unique challenges associated with treating individuals with ASD. Indiana, along with other states, lag in recognizing nationally certified ABA therapists and would do well to either grant state licensure for ABA therapists, ${ }^{260}$ or to amend the autism insurance mandate to include a category of Autism Service Providers.

\section{Treatment Plans}

Several states require a treatment plan as part of the ASD insurance mandates. $^{261}$ States requiring treatment plans as a condition of coverage should clearly outline who is allowed to develop the plan, who must sign the plan, and the necessary elements. For example, insurers under the Indiana mandate were requiring the individual's primary care physician to sign even though he or she had not participated in the plan's development, which made these physicians understandably uncomfortable. ${ }^{262}$ The Indiana Department of Insurance, thus, clarified its guidelines to indicate that the treating physician, rather than the primary care physician, could sign off on the

257. IND. BULL. 136, supra note 106, at 2.

258. Lisa Girion, Ruling Deals a Blow to Denials of Autism Treatment, L.A. TIMES, Oct. 27, 2009, http://articles.latimes.com/2009/oct/27/business/fi-autism27.

259. See supra note 152.

260. See, e.g., Nev. Rev. StAT. AnN. § 641.172 (LexisNexis 2010).

261. See supra note 153.

262. Minutes, supra note 93 , at 5. 
plan. ${ }^{263}$ Finally, state insurance regulating agencies should collaborate with service providers and insurers to develop model treatment plans to use as templates. ${ }^{264}$

\section{Maximum Benefit Amounts}

Nearly every state mandate limits the maximum benefit amounts. ${ }^{265}$ Using a conservative estimate of $\$ 50,000$ per year for $\mathrm{ABA},{ }^{266}$ many state limits would cover just over half the cost. $^{267}$ Limiting ASD services through maximum benefit amounts means that someone, either parents or the state, is left covering the remaining costs. On the other hand, setting a maximum benefit amount helps control costs and may encourage families and providers to search for more cost-effective ways to deliver services. One unique approach to controlling costs would be to have different maximum yearly benefits based on the type of plan. For example, Kentucky sets a higher amount for large group plans than what is required for small group and individual plans. ${ }^{268}$

\section{Types of Policies Covered}

To fully realize the benefits of insurance coverage for ASD treatments, a large number of individuals with ASD would have to be in plans covered by the mandate. Even in states that have passed ASD insurance reform, many individuals are still unable to receive treatment because their health insurance plans are not covered under the mandate. ${ }^{269}$ In Indiana, approximately seventy percent of the families who have health coverage through their employer are on self-funded plans and, thus, not covered by

263. Id.

264. Model treatment plans would be used not to describe specific treatment goals (as those should be individualized to the person), but to ensure that all the proper information is included in a usable format.

265. See supra note 164.

266. Autism Speaks, Arguments, supra note 4, at 8. See also Bunce \& Wieske, supra note 55 , at 2 .

267. ARiz. Rev. Stat. AnN. $§ ~ 20-826.04(D)(1)$, (2) (LexisNexis 2010); Colo. Rev. Stat. § 10-16-104(1.4)(b)(I) (2010); ConN. Gen. Stat. § 38a-514b(d) (2010); Fla. STAT. § 627.6686(4)(b) (2010); 215 Ill. ComP. StAT. ANN. 5/356z.14(b) (LexisNexis 2011); IowA Code § 514C.26(3) (West 2010); La. Rev. Stat. Ann. § 22:1050(D)(1) (2009); Me. Rev. StAT. AnN. 24-A, § 2766(2)(D) (2010); Mo. AnN. StAT. § 376.1224(5) (West 2010); Mont. Code Ann. § 33-22-515(4)(a)(i) (2009); Nev. Rev. Stat. AnN. § 689B.0335(2)(a) (LexisNexis 2010); N.J. STAT. AnN. § 17B:27-46.1ii(1)(c)(3)(a) (West 2009); N.M. STAT. AnN. § 59A-23-11(B)(2) (LexisNexis 2009); 40 PA. StAT. AnN. § 764h(b) (West 2009).

268. Compare Ky. Rev. StAT. AnN. §§ 304.17A-142(2)(a), (b) (West 2010) with Ky. Rev. Stat. AnN. § 304.17A-143(2) (West 2010).

269. Autism Speaks, Response, supra note 200. 
the mandate. ${ }^{270}$ Nationally, Autism Speaks estimates that approximately two-thirds of employees of state, local, and tribal governments are enrolled in self-funded health insurance plans. ${ }^{271}$ Given that so many people are covered under self-insured plans, an ASD mandate does not lead to providing substantially more people with a given benefit. ${ }^{272}$ Many ASD insurance statutes also exclude individual policies or small group plans from their requirements. ${ }^{273}$ For states to realize fully the long-term benefits of insurance coverage for ASD services, laws exempting self-funded, small group or individual plans from mandates would need to change. ${ }^{274}$ Removing exemptions, however, would likely result in significant political backlash and, thus, is not likely a viable solution. Still, until mandates cover more individuals with ASDs, their impact is unlikely to be felt and the bulk of the burden will still fall to state-sponsored services.

\section{CONCLUSION}

In conclusion, ASDs are complex and costly disorders that cause extraordinary financial hardships to parents and states. Current state systems providing treatment for individuals with ASDs serve too few and suffer from high staff turnover and low quality. It is in society's best interest to secure early intervention for children with ASDs to save money on costly, long-term care. Improving state-sponsored services is a laudable goal; however, these changes may create an undue financial burden on already starved state budgets. Health insurance providers have historically avoided covering treatments for children with autism through various risk-shielding techniques, and consumer protection tools are often not a cost-effective or timely way to secure treatment.

While controversial, ASD insurance reform is currently the best way to ensure treatment for individuals with ASDs. However, even liberal mandates, like Indiana's, have problems and cover less than one-third of children with ASDs. ${ }^{275}$ There are several ways to address these problems including: eliminating age restrictions; changing diagnostic definitions to include both old and new DSM conceptualizations; allowing flexibility in

270. Minutes from the Tex. Dep't Ins., supra note 93, at 4.

271. Autism Speaks, Response, supra note 200.

272. See JENSEN \& MorRisey, supra note 232, at i.

273. See supra notes 181 (small groups exempted) and 187 (individual policies exempted).

274. Self-funded plans are generally regulated by ERISA (29 U.S.C. $\S \S 1001$ ) and thus would need to be addressed through those mechanisms. ATAA would amend ERISA to require self-funded plans to provide coverage. Autism Treatment Acceleration Act of 2009 (“ATAA”), S. 819, 111th Cong. § 12 (2009).

275. Autism Speaks, Response, supra note 200; Minutes, supra note 93, at 4 (noting that approximately seventy percent of families are covered by self-funded plans, which are not subject to the ASD insurance mandate). 
the statute for including emerging treatments; granting state licenses to nationally certified ABA therapists; developing a model treatment plan with clear guidelines; removing maximum benefit limits; and changing laws to maximize the number of individuals with ASDs covered under the mandate. It is true that there is no "magic bullet" when it comes to ASDs. However, at this point, autism insurance mandates are the only weapons we have to help children with ASDs reach their full potential. 